\title{
DEPOSITION AND CHEMISTRY OF BOTTOM SEDIMENTS IN COCHITI LAKE, NORTH-CENTRAL NEW MEXICO
}

U.S. DEPARTMENT OF THE INTERIOR U.S. GEOLOGICAL SURVEY

Water-Resources Investigations Report 99-4258

Prepared in cooperation with the PUEBLO DE COCHITI

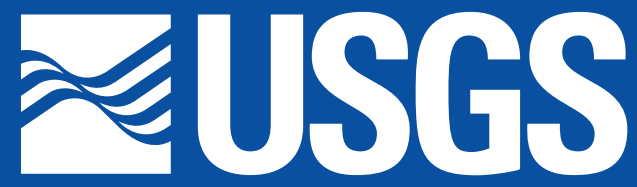




\section{DEPOSITION AND CHEMISTRY OF BOTTOM SEDIMENTS IN COCHITI LAKE, NORTH-CENTRAL NEW MEXICO}

By Jennifer T. Wilson and Peter C. Van Metre

\section{U.S. GEOLOGICAL SURVEY}

Water-Resources Investigations Report 99-4258

Prepared in cooperation with the

PUEBLO DE COCHITI 


\section{CONTENTS}

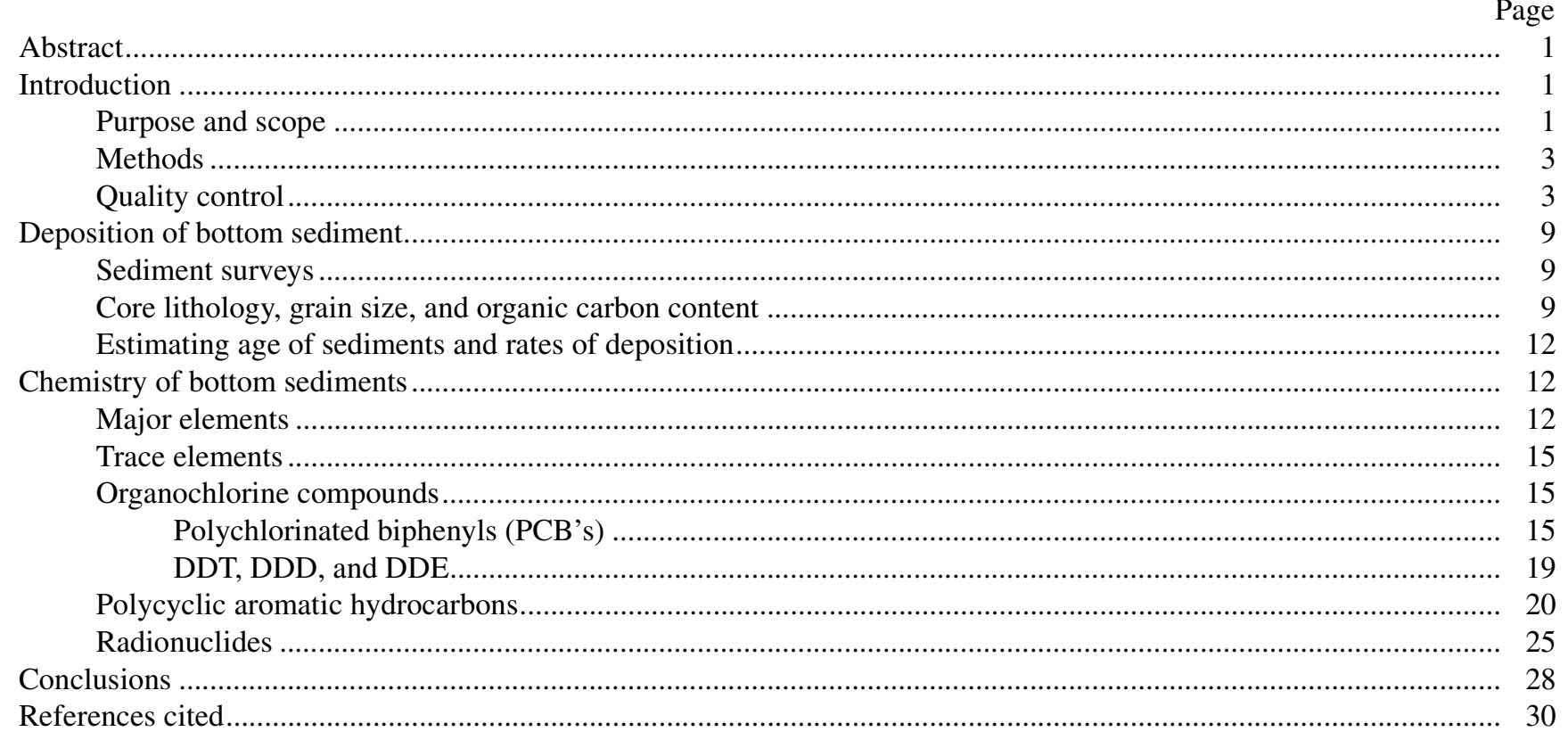

\section{FIGURES}

1. Map showing contributing area of Cochiti Lake and location of sediment coring sites

2-12. Graphs showing:

2. (A) Longitudinal profile of reservoir showing historical sedimentation and migration of sediment

front. (B) Suspended-sediment discharge of the Rio Grande at Otowi Bridge, N. Mex.

3. Grain size in a gravity core at site R1 (A) and box cores (B) and percentage of organic carbon in a gravity core (C) and box core at site R1 (D) from Cochiti Lake

4. Major element concentrations in a gravity core and box core at site R1 from Cochiti Lake ......................... 13

5. Major element concentrations in box cores from Cochiti Lake ................................................................ 14

6. Trace-element concentrations in a gravity core and box core at site R1 from Cochiti Lake......................... 16

7. Trace-element concentrations in box cores from Cochiti Lake.................................................................. 17

8. Concentrations of DDT and its metabolites in a gravity core (A) and box cores (B) from Cochiti Lake........ 21

9. Polycyclic aromatic hydrocarbon (PAH) concentrations (A-D), PAH sums (E), and the ratio of the sum of 2- and 3-ringed PAH's to total combustion PAH (F) in a gravity core from Cochiti Lake.................... 23

10. Polycyclic aromatic hydrocarbon (PAH) concentrations (A-D), PAH sums (E), and the ratio of the sum of 2- and 3-ringed PAH's to total combustion PAH (F) in box cores from Cochiti Lake ......................... 24

11. Uranium and thorium radionuclide activities in a gravity core from Cochiti Lake....................................... 26

12. Uranium and thorium radionuclide activities in box cores from Cochiti Lake ........................................... 27

13. Plutonium activities in a gravity core $(\mathrm{A}$ and $\mathrm{B})$ and box cores $(\mathrm{C}$ and $\mathrm{D})$ from Cochiti Lake.......................... 29 


\section{TABLES}

1. Parameters analyzed for and their reporting levels in Cochiti Lake bottom-sediment samples

2. Polycyclic aromatic hydrocarbons (PAH's) analyzed for, number of detections, and range and median of concentrations, in micrograms per kilogram, in Cochiti Lake bottom-sediment samples

3. Counting and total errors of radionuclide analyses

4. Trace-element sediment-quality guidelines compared to concentration ranges, in micrograms per gram, in Cochiti Lake gravity core

5. Concentrations of polychlorinated biphenals (PCB's), in micrograms per kilogram, in Cochiti Lake gravity core from site R1 and box cores from all sites

6. Organic sediment-quality guidelines compared to concentration ranges, in micrograms per kilogram, in Cochiti Lake gravity core

CONVERSION FACTORS AND VERTICAL DATUM

\begin{tabular}{rrll}
\hline Multiply & By & To obtain \\
\hline foot & 0.3048 & meter \\
ton & 0.9072 & metric ton \\
\hline
\end{tabular}

Sea level: In this report, "sea level" refers to the National Geodetic Vertical Datum of 1929-a geodetic datum derived from a general adjustment of the first-order level nets of the United States and Canada, formerly called Sea Level Datum of 1929. 


\title{
Deposition and Chemistry of Bottom Sediments in Cochiti Lake, North-Central New Mexico
}

\author{
By Jennifer T. Wilson and Peter C. Van Metre
}

\section{ABSTRACT}

Bottom sediments were sampled at seven sites in Cochiti Lake in September 1996. Sediment cores penetrating the entire lacustrine sediment sequence were collected at one site near the dam. Surficial sediments were sampled at the near-dam site and six other sites located along the length of the reservoir. Analyses included grain size, major and trace elements, organochlorine compounds, polycyclic aromatic hydrocarbons (PAH's), and radionuclides. Concentrations of trace elements, organic compounds, and radionuclides are similar to those in other Rio Grande reservoirs and are low compared to published sediment-quality guidelines. Most elements and compounds that were detected did not show trends in the ageestimated sediment cores with the exception of a decreasing trend in total DDT concentrations from about 1980 to 1992. The mixture of PAH's suggests that the increase is caused by inputs of fuel-related $\mathrm{PAH}$ and not combustion-related PAH.

\section{INTRODUCTION}

Cochiti Lake is on the Cochiti Indian Reservation in north-central New Mexico (fig. 1). Storage of water from the Rio Grande and the Santa Fe River began in November 1973 (Borland and Ong, 1995). The permanent pool elevation of approximately 5,340 feet (ft) was reached in December 1975 (Department of the Army, 1996). Cochiti Lake has a drainage area of approximately 38,600 square kilometers $\left(\mathrm{km}^{2}\right)$, which includes $7,600 \mathrm{~km}^{2}$ of closed basin in the San Luis Valley, Colo. A detailed description of the drainage area, including geology, soils, and climate, was published by the Department of the Army (1996). Cochiti Lake is used for flood control, sediment control, irrigation, and recreation (Ruddy and Hitt, 1990).

Los Alamos National Laboratory (LANL) has operated as a Federal facility since 1943. It is located on Pajarito Mesa on the east flank of the Jemez Mountains, within the drainage area of Cochiti Lake. Many activities and operations at LANL involve or produce liquids, solids, and gases that contain radioactive and (or) nonradioactive hazardous materials (Los Alamos National Laboratory, 1995). In 1996, the U.S. Geological Survey (USGS), in cooperation with Pueblo de Cochiti, began a study to evaluate the chemistry of bottom sediments in Cochiti Lake.

\section{Purpose and Scope}

This report evaluates the occurrence and trends of major and trace elements and selected contaminants in the bottom sediments of Cochiti Lake. Gravity cores collected at a single site provided sediment samples for the analysis of the historical occurrences and trends of selected compounds, and box cores collected at six sites along the length of the reservoir provided sediment samples used to describe the spatial occurrence of selected compounds. Compounds studied include major and trace elements, organochlorine pesticides, polychlorinated biphenyls (PCB's), polycyclic aromatic hydrocarbons (PAH's), and several radionuclides. The study used reservoir paleolimnology following approaches used by the USGS National Water-Quality Assessment Program in other Rio Grande reservoirs (Van Metre and others, 1996a) and elsewhere (Callender and Van Metre, 1997; Van Metre and others, 1997). 

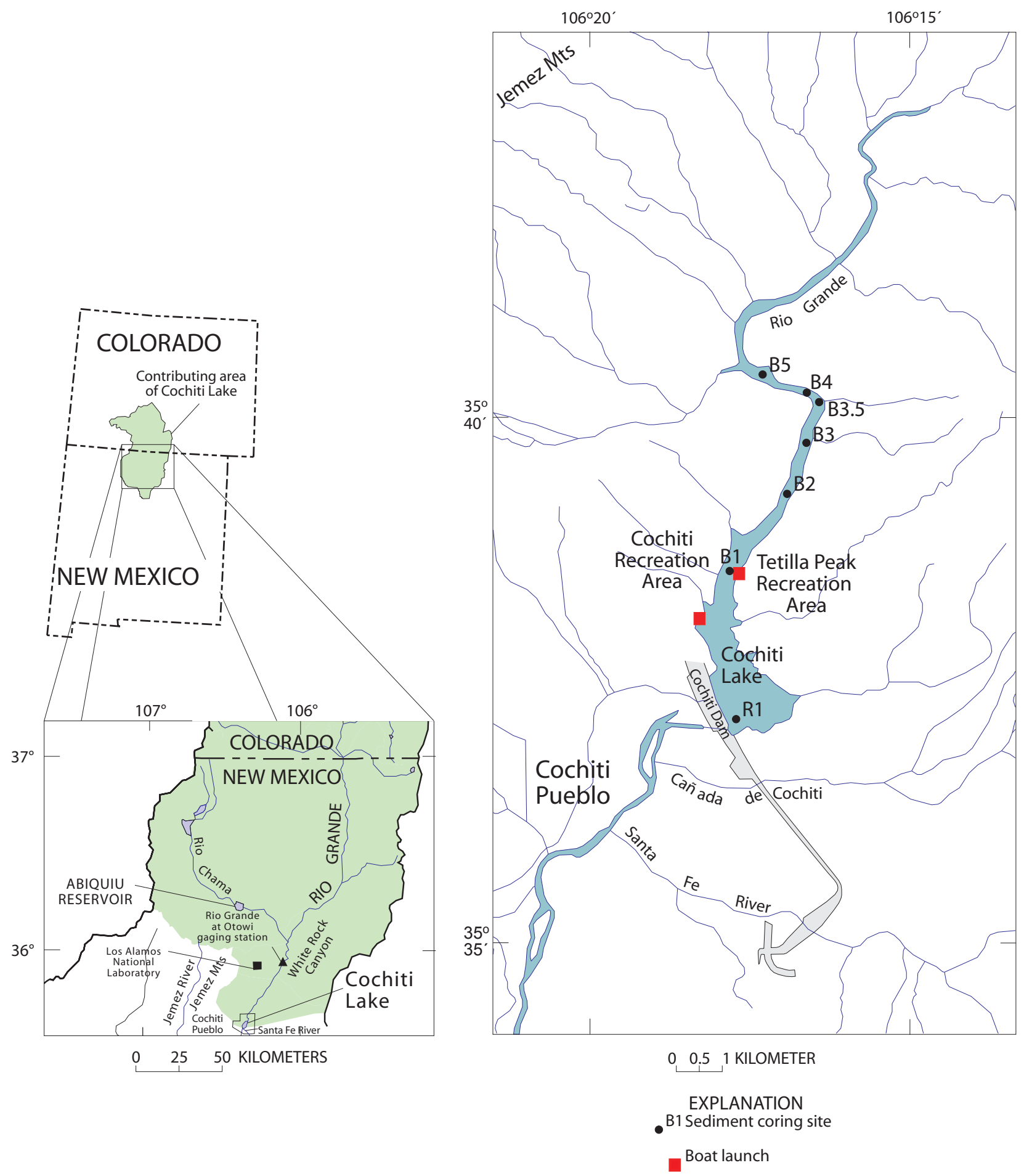

Figure 1. Contributing area of Cochiti Lake and location of sediment coring sites. 


\section{Methods}

Bottom sediment cores were collected using a Benthos gravity corer (4 meters $(\mathrm{m})$ long and 6.3 centimeters $(\mathrm{cm})$ in diameter) and a Wildco box corer $(15 \times 15 \times 20 \mathrm{~cm})$. Corers were lowered from a $15-\mathrm{ft}$ aluminum A-frame on a custom-built pontoon boat. Bottom sediments were cored at seven sites in Cochiti Lake (fig. 1) in September 1996. The primary coring location, site R1, was located approximately $150 \mathrm{~m}$ northeast of Cochiti Dam in the right stream channel of the originally braided Rio Grande channel. The remaining six sampling sites (B1 through B5) were located along the length of the reservoir and included two sites with relatively shallow water depths near the inlet of the Rio Grande.

Five gravity cores (of varying lengths) and one box core were collected at site R1. Four gravity cores and the box core were extruded vertically and subsampled into discreet intervals on site. The fifth gravity core was split longitudinally and visually described in the field. The gravity core analyzed for major and trace elements was subsampled at $5-\mathrm{cm}$ intervals along its $133-\mathrm{cm}$ length. The gravity core analyzed for organic compounds, including organochlorines and PAH's, was subsampled at 12-cm intervals from 0 to $120 \mathrm{~cm}$. The gravity core analyzed for radionuclides was subsampled at $13-\mathrm{cm}$ intervals from 0 to $156 \mathrm{~cm}$. The gravity core for archiving was subsampled at $5-\mathrm{cm}$ intervals along its $125-\mathrm{cm}$ length. The box core analyzed for major and trace elements and organic carbon was subsampled at 2 -cm intervals along its $18-\mathrm{cm}$ length. A portion of the top $5 \mathrm{~cm}$ of this box core was analyzed for grain size, organochlorine compounds, PAH's, and radionuclides.

At the other six sites (B1 through B5), only box cores were collected. Gravity cores were not collected at sites B1 through B5 because sedimentation has probably not been continuous since the date of impoundment, limiting the historical significance of gravity cores. Also, the sediments are more likely to be disturbed by flood events in these shallow, more upstream areas. At each of these six sites, three box cores were collected and the top $5 \mathrm{~cm}$ from each was composited for analysis. Samples were analyzed for grain size, major and trace elements, organochlorine compounds, PAH's, and radionuclides.

Analyses of subsamples from the cores were analyzed at different laboratories. The USGS sediment laboratory in Iowa City, Iowa, conducted grain-size analyses by wet sieving the sand fraction and measuring silt- and clay-sized fractions using the pipet method (Guy, 1969). Analytical methods included the determination of percent organic carbon by a modification of the method in Hendricks and Eganhouse (1992); determination of major and trace elements by inductively coupled plasma-atomic emission spectrometry; determination of chromium, lead, and zinc by graphite-furnace atomic adsorption; determination of mercury by cold vapor atomic adsorption; and determination of selenium by hydride generation atomic adsorption spectrometry by the USGS National Research Program laboratory in Reston, Va. (Lichte and others, 1987; Fishman, 1993). Organic compounds were analyzed by the USGS National Water Quality Laboratory (NWQL) in Denver, Colo. Organochlorine compounds were extracted and analyzed using the procedures described by Foreman and others (1994) and the quantification procedures described by Wershaw and others (1987). PAH analyses followed the extraction and cleanup procedures of Furlong and others (1996) with selected ion monitoring for PAH's by gas chromatography/mass spectrometry (Edward Furlong, U.S. Geological Survey, written commun., 1996). Radionuclides were analyzed by Quanterra Environmental Services in Richland, Wash. Analyses for ${ }^{137} \mathrm{Cs},{ }^{210} \mathrm{~Pb}$, and ${ }^{226} \mathrm{Ra}$ were performed by gamma spectrometry and ${ }^{234} \mathrm{U}$, ${ }^{235} \mathrm{U},{ }^{238} \mathrm{U},{ }^{230} \mathrm{Th},{ }^{232} \mathrm{Th},{ }^{238} \mathrm{Pu}$, and ${ }^{239,240} \mathrm{Pu}$ by alpha spectrometry. Splits of samples from this core were provided to LANL for analysis of plutonium by mass spectrometry (Gallaher and others, 1999). Parameters analyzed for and their reporting levels are presented in tables 1 and 2 .

\section{Quality Control}

Several samples were split at the various laboratories and analyzed in duplicate. The relative percent difference (RPD) is a measure of the variability in the values produced by the analytical method. RPD was calculated for each pair of duplicate samples by the equation:

$$
R P D=100 \times\left|\frac{\text { sample } 1-\text { sample2 }}{\left(\frac{\text { sample } 1+\text { sample } 2}{2}\right)}\right|
$$

where sample 1 and sample 2 are the concentrations in duplicate samples. 
Table 1. Parameters analyzed for and their reporting levels in Cochiti Lake bottom-sediment samples

[Reporting levels for organochlorine compounds vary for the volume of sample submitted for analysis. wt. \%, weight percent; $\mu \mathrm{g} / \mathrm{g}$, micrograms per gram; $\mu \mathrm{g} / \mathrm{kg}$, micrograms per kilogram; $\mathrm{PCB}$, polychlorinated biphenyl; $\mathrm{PCN}$, polychlorinated naphthalene; $\mathrm{pCi} / \mathrm{g}$, picocuries per gram]

\begin{tabular}{|c|c|c|c|}
\hline Parameter & $\begin{array}{c}\text { Reporting } \\
\text { level }\end{array}$ & Parameter & $\begin{array}{c}\text { Reporting } \\
\text { level }\end{array}$ \\
\hline Major elements & wt. \% & Trace elements (continued) & $\mu \mathrm{g} / \mathbf{g}$ \\
\hline Aluminum, $\mathrm{Al}$ & 0.05 & Uranium, U & 2.0 \\
\hline Calcium, $\mathrm{Ca}$ & 0.05 & Vanadium, V & 2.0 \\
\hline Iron, $\mathrm{Fe}$ & 0.05 & Yttrium, Y & 2.0 \\
\hline Potassium, $\mathrm{P}$ & 0.05 & Ytterbium, Yb & 2.0 \\
\hline Magnesium, Mg & 0.005 & Zinc, $\mathrm{Zn}$ & 4.0 \\
\hline Sodium, $\mathrm{Na}$ & 0.005 & Organochlorine compounds & $\mu \mathrm{g} / \mathrm{kg}$ \\
\hline Phosphorus, $\mathrm{P}$ & 0.005 & Aldrin & $0.1-0.3$ \\
\hline Carbon, organic & 0.1 & Chlordane & $1.0-2.5$ \\
\hline Carbon, total & 0.1 & DDD & $0.1-0.3$ \\
\hline Trace elements & $\mu \mathrm{g} / \mathrm{g}$ & DDE & $0.1-0.3$ \\
\hline Silver, Ag & 0.1 & DDT & $0.1-0.3$ \\
\hline Arsenic, As & 0.1 & Dieldrin & $0.1-0.3$ \\
\hline Gold, $\mathrm{Au}$ & 8.0 & Endosulfan & $0.1-0.3$ \\
\hline Barium, Ba & 1.0 & Endrin & $0.1-0.3$ \\
\hline Beryllium, Be & 1.0 & PCB Aroclor 1242 & $1.0-3.0$ \\
\hline Bismuth, Bi & 0.1 & PCB Aroclor 1254 & $1.0-3.0$ \\
\hline Cadmium, Cd & 0.1 & PCB Aroclor 1260 & $1.0-3.0$ \\
\hline Cerium, $\mathrm{Ce}$ & 4.0 & Gross PCN's & $1.0-3.0$ \\
\hline Cobalt, Co & 1.0 & Heptachlor & $0.1-0.3$ \\
\hline Chromium, $\mathrm{Cr}$ & 0.1 & Heptachlor epoxide & $0.1-0.3$ \\
\hline Copper, $\mathrm{Cu}$ & 1.0 & Lindane & $0.1-0.3$ \\
\hline Europium, Eu & 2.0 & Methoxychlor & $0.1-0.3$ \\
\hline Gallium, Ga & 4.0 & Mirex & $0.1-8.0$ \\
\hline Mercury, Hg & 0.02 & Perthane & $1.0-3.0$ \\
\hline Holmium, Ho & 4.0 & Toxaphene & $10-30$ \\
\hline Lanthanum, La & 2.0 & Other organic compounds & $\mu \mathrm{g} / \mathrm{kg}$ \\
\hline Lithium, Li & 2.0 & PAH's (listed in table 2) & \\
\hline Manganese, $\mathrm{Mg}$ & 4.0 & Phenol & 10 \\
\hline Molybdenum, $\mathrm{Mb}$ & 1.0 & p-cresol & 10 \\
\hline Niobium, Ni & 4.0 & c8-alkyl-phenol & 10 \\
\hline Neodymium, $\mathrm{Nd}$ & 4.0 & Radionuclides & $\mathbf{p C i} / \mathrm{g}$ \\
\hline Nickel, Ni & 2.0 & Cesium-137, ${ }^{137} \mathrm{Cs}$ & 0.02 \\
\hline Lead, $\mathrm{Pb}$ & 0.1 & Lead- $210,{ }^{210} \mathrm{~Pb}$ & 0.1 \\
\hline Antimony, Sb & 0.1 & Radium-226, ${ }^{226} \mathrm{Ra}$ & 0.4 \\
\hline Scandium, Sc & 2.0 & Uranium-234, ${ }^{234} \mathrm{U}$ & $0.01-0.04$ \\
\hline Selenium, Se & 0.1 & Uranium-235, ${ }^{235} \mathrm{U}$ & $0.01-0.03$ \\
\hline Tin, Sn & 5.0 & Uranium-238, ${ }^{238} \mathrm{U}$ & $0.01-0.04$ \\
\hline Strontium, Sr & 2.0 & Thorium-230, ${ }^{230} \mathrm{Th}$ & $0.005-0.02$ \\
\hline Tantalum, Ta & 40.0 & Thorium-232, ${ }^{232} \mathrm{Th}$ & $0.004-0.02$ \\
\hline Thorium, Th & 4.0 & Plutonium-238, ${ }^{238} \mathrm{Pu}$ & $0.0002-0.002$ \\
\hline Titanium, Ti & 0.005 & Plutonium-239, 240, ${ }^{239,240} \mathrm{Pu}$ & $0.0002-0.001$ \\
\hline
\end{tabular}


Table 2. Polycyclic aromatic hydrocarbons (PAH's) analyzed for, number of detections, and range and median of concentrations, in micrograms per kilogram, in Cochiti Lake bottom-sediment samples

[PAH's are listed in order of increasing molecular weight, and parent PAH's are indicated in bold type. Ten gravity core intervals and seven box core samples were submitted for analysis. BRL, below reporting level; <, less than]

\begin{tabular}{|c|c|c|c|c|}
\hline PAH & $\begin{array}{l}\text { Number of } \\
\text { detections in } \\
\text { gravity core }\end{array}$ & $\begin{array}{l}\text { Concentration range in } \\
\text { gravity core (and median) }\end{array}$ & $\begin{array}{c}\text { Number of } \\
\text { detections in box } \\
\text { cores }\end{array}$ & $\begin{array}{l}\text { Concentration range in box } \\
\text { cores (and median) }\end{array}$ \\
\hline Naphthalene & 9 & BRL - $3.33(2.14)$ & 7 & $13.4-40.8(21.3)$ \\
\hline $\mathrm{C} 1-128$ isomers & 9 & $<10-25.9(17.0)$ & 7 & $40.9-185(104)$ \\
\hline 2-Ethylnaphthalene & 1 & $<10-12.7(<10)$ & 6 & BRL - 4.65 (3.65) \\
\hline 2,6-Dimethylnaphthalene & 10 & $27.1-73.9(44.9)$ & 7 & $4.87-112(25.6)$ \\
\hline 1,6-Dimethylnaphthalene & 9 & BRL - $6.30(3.94)$ & 7 & $6.98-18.9(15.9)$ \\
\hline $\mathrm{C} 2-128$ isomers & 10 & $38.1-88.0(56.6)$ & 7 & $24.6-167(72.3)$ \\
\hline Acenaphthylene & 0 & & 2 & BRL - $1.51(<10)$ \\
\hline 1,2-Dimethylnaphthalene & 0 & & 6 & BRL - $3.16(2.12)$ \\
\hline Acenaphthene & 0 & & 0 & \\
\hline C3-128 isomers & 6 & $<10-12.6(6.06)$ & 7 & $14.4-45.9(30.4)$ \\
\hline 2,3,6-Trimethylnaphthalene & 1 & BRL $-0.460(<10)$ & 3 & BRL - $1.96(<10)$ \\
\hline 9H-Fluorene & 4 & BRL - $1.94(<10)$ & 5 & BRL - 3.94 (1.76) \\
\hline C4-128 isomers & 2 & BRL - $5.31(<10)$ & 4 & BRL - $30.2(15.5)$ \\
\hline 1-Methyl-9H-fluorene & 6 & BRL - $3.05(1.60)$ & 7 & $2.26-6.51(4.46)$ \\
\hline $\mathrm{C} 1-166$ isomers & 8 & BRL - $8.71(5.58)$ & 6 & BRL - $16.9(12.6)$ \\
\hline Dibenzothiophene & 1 & BRL - $1.15(<10)$ & 1 & BRL - $1.16(<10)$ \\
\hline Phenanthrene & 10 & $2.91-11.3(5.40)$ & 7 & $8.13-25(16.0)$ \\
\hline Anthracene & 5 & BRL - $1.92(0.88)$ & 6 & BRL - $5.28(1.81)$ \\
\hline Acridine & 1 & BRL - $3.74(<10)$ & 0 & \\
\hline Phenanthridine & 1 & BRL - $6.74(<10)$ & 0 & \\
\hline
\end{tabular}


Table 2. Polycyclic aromatic hydrocarbons (PAH's) analyzed for, number of detections, and range and median of concentrations, in micrograms per kilogram, in Cochiti Lake bottom-sediment samples--Continued

\begin{tabular}{|c|c|c|c|c|}
\hline PAH & $\begin{array}{c}\text { Number of } \\
\text { detections in } \\
\text { gravity core }\end{array}$ & $\begin{array}{l}\text { Concentration range in } \\
\text { gravity core (and median) }\end{array}$ & $\begin{array}{c}\text { Number of } \\
\text { detections in box } \\
\text { cores }\end{array}$ & $\begin{array}{l}\text { Concentration range in box } \\
\text { cores (and median) }\end{array}$ \\
\hline 9H-Carbazol & 8 & BRL - $2.50(2.02)$ & 4 & BRL - $5.33(3.22)$ \\
\hline C5-128 isomers & 0 & & 4 & $<10-21.9(10.2)$ \\
\hline $\mathrm{C} 2-166$ isomers & 1 & BRL - $5.57(<10)$ & 1 & BRL - $13.6(<10)$ \\
\hline 2-Methylanthracene & 5 & BRL - $1.78(0.25)$ & 5 & BRL - 1.92 (1.43) \\
\hline 4,5-Methylenephenanthrene & 7 & BRL - $1.94(1.31)$ & 1 & BRL - $1.58(<10)$ \\
\hline $\mathrm{C} 1-178$ isomers & 10 & $4.59-11.5(7.48)$ & 7 & $12.8-37.5(24.4)$ \\
\hline 1-Methylphenanthrene & 10 & $1.09-2.45(1.42)$ & 7 & $7.34-20.6(13.2)$ \\
\hline $\mathrm{C} 3-166$ isomers & 0 & & 0 & \\
\hline $\mathrm{C} 2-178$ isomers & 7 & $<10-12.0(7.19)$ & 7 & $27.5-76.1(46.3)$ \\
\hline Fluoranthene & 10 & $4.64-12.8(7.46)$ & 7 & $2.92-10.8(6.16)$ \\
\hline Pyrene & 10 & $4.38-13.8(6.82)$ & 6 & BRL - $10.5(5.91)$ \\
\hline C3-178 isomers & 3 & BRL - $7.14(<10)$ & 6 & $<10-52.0(27.8)$ \\
\hline $\mathrm{C} 4-178$ isomers & 0 & & 0 & \\
\hline 1-Methylpyrene & 3 & BRL - $1.88(<10)$ & 0 & \\
\hline $\mathrm{C} 1-202$ isomers & 10 & $12.4-21.9(17.9)$ & 5 & $<10-118(28.1)$ \\
\hline C2-202 isomers & 8 & BRL - 7.37 (5.02) & 1 & BRL - $4.4(<10)$ \\
\hline C5-178 isomers & 1 & BRL - $2.25(<10)$ & 5 & BRL - $17.7(13.8)$ \\
\hline $\operatorname{Benz}(a)$ anthracene & 10 & $1.64-7.75(2.43)$ & 4 & BRL - $3.80(1.4)$ \\
\hline Chrysene & 10 & $3.43-9.16(5.93)$ & 7 & $1.59-8.06(4.74)$ \\
\hline C3-202 isomers & 0 & & 0 & \\
\hline $\mathrm{C} 1-228$ isomers & 9 & BRL - 7.3 (5.34) & 3 & BRL - $7.63(<10)$ \\
\hline
\end{tabular}


Table 2. Polycyclic aromatic hydrocarbons (PAH's) analyzed for, number of detections, and range and median of concentrations, in micrograms per kilogram, in Cochiti Lake bottom-sediment samples--Continued

\begin{tabular}{|c|c|c|c|c|}
\hline PAH & $\begin{array}{l}\text { Number of } \\
\text { detections in } \\
\text { gravity core }\end{array}$ & $\begin{array}{l}\text { Concentration range in } \\
\text { gravity core (and median) }\end{array}$ & $\begin{array}{c}\text { Number of } \\
\text { detections in box } \\
\text { cores }\end{array}$ & $\begin{array}{l}\text { Concentration range in box } \\
\text { cores (and median) }\end{array}$ \\
\hline C4-202 isomers & 0 & & 0 & \\
\hline C5-202 isomers & 0 & & 0 & \\
\hline $\mathrm{C} 2-228$ isomers & 5 & BRL - $9.02(2.21)$ & 2 & BRL - $13.2(<10)$ \\
\hline Benzo(b)fluoranthene & 10 & $3.52-7.31(5.24)$ & 7 & $1.04-6.96(1.67)$ \\
\hline Benzo(k)fluoranthene & 9 & BRL - 10.4 (3.30) & 4 & BRL - $3.34(1.00)$ \\
\hline Benzo(e)pyrene & 10 & $3.23-6.61(5.24)$ & 6 & BRL - 6.94 (3.49) \\
\hline Benzo(a)pyrene & 10 & $1.74-10.2(2.95)$ & 3 & BRL - $4.21(<10)$ \\
\hline Perylene & 10 & $54.7-221(157.5)$ & 3 & $<10-23.8(<10)$ \\
\hline $\mathrm{C} 1-252$ isomers & 5 & BRL - $7.40(1.40)$ & 1 & \\
\hline C3-228 isomers & 1 & BRL - $4.76(<10)$ & 0 & \\
\hline $\mathrm{C} 2-252$ isomers & 3 & BRL - $6.64(<10)$ & 0 & \\
\hline $\mathrm{C} 4-228$ isomers & 0 & & 0 & \\
\hline $\operatorname{Benzo}(\mathbf{g}, \mathbf{h}, \mathbf{i})$ perylene & 6 & BRL - $3.62(2.00)$ & 1 & BRL $-1.27(<10)$ \\
\hline Indeno(1,2,3-cd)pyrene & 6 & BRL - $9.58(2.12)$ & 1 & BRL $-1.12(<10)$ \\
\hline $\operatorname{Dibenzo}(a, h)$ anthracene & 3 & BRL - $2.32(<10)$ & 0 & \\
\hline C3-252 isomers & 0 & & 0 & \\
\hline $\mathrm{C} 4-252$ isomers & 0 & & 0 & \\
\hline C5-228 isomers & 1 & BRL $-1.82(<10)$ & 0 & \\
\hline C5-252 isomers & 0 & & 0 & \\
\hline Coronene & 1 & BRL $-1.13(<10)$ & 0 & \\
\hline
\end{tabular}


Three sample intervals from the gravity core and one sample from the box core at site R1 were analyzed in duplicate for organic carbon. RPD for the four duplicate analyses of organic carbon ranged from 0 to 0.78 percent, and the median was 0.36 percent.

One gravity core sample had duplicate analyses of major and trace elements. Thirty-nine major and trace elements were detected in both duplicate analyses, and 12 of these elements had identical concentrations (mostly two significant figures) in both analyses. The RPD for major elements ranged from 0.26 percent for calcium to 0.76 percent for magnesium (median RPD $=0.39$ percent for eight elements). The RPD for trace elements ranged from 0 percent for Ag, $\mathrm{Ba}, \mathrm{Bi}, \mathrm{Cd}, \mathrm{Hg}, \mathrm{Mn}, \mathrm{Mb}, \mathrm{Nb}, \mathrm{Sc}, \mathrm{Sr}, \mathrm{Y}$, and $\mathrm{Yb}$ to 4.5 percent for antimony (median RPD $=0.29$ percent for 31 elements). The RPD for PAH compounds ranged from 0.0 percent for 4,5-methylenephenanthrene to 68.0 percent for benzo(k)fluoranthene (median RPD = 12.6 percent for 31 detections out of 64 reported PAH compounds). The duplicate sample for organochlorine pesticide analysis was ruined during preparation at the NWQL.
The NWQL analyzed method blanks, method spikes, certified reference material, and a duplicate sample for each batch of samples submitted for organic compound analysis. The results met established NWQL control limits (Pritt and Raese, 1992).

Radionuclide results included counting errors and total errors for each sample. Counting error is the statistical uncertainty in the count contributed by background sources. Total error is the counting uncertainty plus the uncertainty in equipment calibration. These errors are reported in table 3 . One interval from the gravity core and one box core sample had duplicate radionuclide analyses. The RPD for the gravity core duplicate ranged from 0.56 percent for ${ }^{239,240} \mathrm{Pu}$ to 12.8 percent for ${ }^{238} \mathrm{Pu}$ (median $=2.8$ percent for seven radionuclides). The RPD of the box core duplicate ranged from 0.20 percent for ${ }^{234} \mathrm{U}$ to 24 percent for ${ }^{238} \mathrm{Pu}$ (median $=0.62$ percent for five radionuclides). Plutonium-238 had very low activity values, and even small differences in measured activities between duplicate analyses cause the RPD to be large.

Table 3. Counting and total errors of radionuclide analyses

[--, not reported]

\begin{tabular}{cccccc}
\hline Radionuclide & $\begin{array}{c}\text { Number of } \\
\text { samples }\end{array}$ & $\begin{array}{c}\text { Range of } \\
\text { counting error }\end{array}$ & $\begin{array}{c}\text { Median } \\
\text { counting error }\end{array}$ & $\begin{array}{c}\text { Range of total } \\
\text { error }\end{array}$ & $\begin{array}{c}\text { Median total } \\
\text { error }\end{array}$ \\
\hline${ }^{137} \mathrm{Cs}$ & 13 & $0.066-0.110$ & 0.079 & $0.079-0.120$ & 0.095 \\
${ }^{210} \mathrm{~Pb}$ & 13 & $0.21-0.28$ & 0.24 & $0.37-0.50$ & 0.46 \\
${ }^{226} \mathrm{Ra}$ & 13 & $0.14-0.20$ & 0.18 & $0.18-0.25$ & 0.23 \\
${ }^{238} \mathrm{Pu}$ & 21 & -- & -- & $0.00013-0.0029$ & 0.00059 \\
${ }^{239,240} \mathrm{Pu}$ & 21 & -- & -- & $0.0014-0.0073$ & 0.0033 \\
${ }^{230} \mathrm{Th}$ & 21 & $0.092-0.21$ & 0.11 & $0.14-0.21$ & 0.19 \\
${ }^{232} \mathrm{Th}$ & 21 & $0.086-0.18$ & 0.11 & $0.13-0.19$ & 0.17 \\
${ }^{234} \mathrm{U}$ & 21 & $0.13-0.17$ & 0.14 & $0.18-0.25$ & 0.21 \\
${ }^{235} \mathrm{U}$ & 21 & $0.019-0.039$ & 0.030 & $0.020-0.040$ & 0.030 \\
${ }^{238} \mathrm{U}$ & 21 & $0.13-0.18$ & 0.14 & $0.19-0.26$ & 0.21 \\
\hline
\end{tabular}




\section{DEPOSITION OF BOTTOM SEDIMENT}

\section{Sediment Surveys}

The Department of the Army, U.S. Army Corps of Engineers (USACE) periodically assesses reservoir sedimentation in Cochiti Lake. The elevation of the reservoir's sediment surface, in feet above sea level, was available for surveys conducted in 1972 (before impoundment), 1976, 1979, 1981, 1986, 1991, and 1998 (Department of the Army, 1996; and unpublished data). The USGS recorded depth to the sediment surface at each of the seven coring sites while collecting sediment cores. The reservoir's water elevation during core collection was $1,628 \mathrm{~m}$ above sea level (Department of the Army, oral commun., 1996). Reservoir sediment-surface elevations during sampling in 1996 at each coring site were calculated and compared with previous sediment surveys to locate the sampling sites relative to historical sediment deposition and to assess the extent of sedimentation at each coring site over the past 5 years. A sediment front, marked by a sudden change from deep to shallow water depths, was profiled in the 1981, 1986, 1991, and 1998 sediment surveys between 6 and $8 \mathrm{~km}$ upstream from the dam (fig. 2A). Bottom sediment coring sites B3, B3.5, and B4 were located along this sediment front in 1996, as shown in figure $2 \mathrm{~A}$.

The USGS monitors suspended-sediment discharge at a gaging station on the Rio Grande at Otowi Bridge (station 08313000) about $27 \mathrm{~km}$ upstream from Cochiti Lake. The total suspendedsediment discharge, in tons per year (tons/yr), recorded at Otowi Bridge since the date of reservoir construction is compiled and illustrated in figure $2 \mathrm{~B}$. The total suspended-sediment discharge was typically about 1.5 million tons/yr with a few exceptions. Years in which relatively high suspended-sediment discharge was recorded were typically followed by progradation of the sediment front in Cochiti Lake.

In the 5-year period between the 1981 and 1986 sediment surveys, the crest of the sediment front built out, or prograded, approximately $0.5 \mathrm{~km}$, resulting in an average progradation rate of $100 \mathrm{~m} / \mathrm{yr}$. The sediment front prograded from 1986 to 1991 and from 1991 to 1996 at estimated average rates of $145 \mathrm{~m} / \mathrm{yr}$ and $250 \mathrm{~m} / \mathrm{yr}$, respectively. The large total suspendedsediment discharges recorded at Otowi Bridge in 1991 and 1995 have contributed to the greater rate of progradation in the 1991-96 period. The extremely high suspended-sediment discharge in 1995 coincides with a large progradation of the sediment front documented during 1996 core collection. A more recent sedimentation survey, performed by the USACE in 1998, shows the sediment surface at lower elevations near the crest than in 1996. The sediment front may have slumped or moved in the downstream direction from 1996 to 1998.

\section{Core Lithology, Grain Size, and Organic Carbon Content}

One gravity core from the primary coring location (R1) was visually described in the field. The core was $117 \mathrm{~cm}$ long and was the only gravity core that did not penetrate the prereservoir surface. Sediments were fine grained throughout the length of the core. The upper $25 \mathrm{~cm}$ of the core was dark yellowish brown (10YR 4/2; Geological Society of America, 1991) with a high water content and no visible benthic invertebrates. The core was of similar color and became firmer down to $73 \mathrm{~cm}$. Below $73 \mathrm{~cm}$, the sediment gradually became light tan (5YR 4/1) followed by a stiff, dark-yellowish-brown (5Y 4/1) zone at 91 to $93 \mathrm{~cm}$. The sediment remained firm and the same color to the bottom of the core with the exception of a prominent dark-olive-black (5Y 2/1) zone at 108 to $112 \mathrm{~cm}$.

Grain-size analyses at the primary coring location (R1) indicated sediments greater than 99 weight percent silt and clay (less than 0.062 millimeter $(\mathrm{mm})$ ) along the full length of the core and a median of 94 weight percent clay-sized particles (less than 0.004 $\mathrm{mm})$. The percentage by weight of clay-sized particles decreased slightly below $130 \mathrm{~cm}$ (fig. 3A). Grain-size analyses were also performed on the box cores of surficial sediments collected along the length of Cochiti Lake. The percentage of silt- and clay-sized particles has little variation along the length of the reservoir, ranging from 91.7 to 100 percent. Clay-sized particles decreased from 92.9 percent at primary coring location R1 to 26.2 percent at the farthest upstream sampling site, B5 (fig. 3B). This trend is typical in reservoirs because coarser grained sediments fall out of suspension first as water velocity slows in the upper part of the reservoir, whereas finer grained sediments stay in suspension longer and are transported farther down the reservoir. 


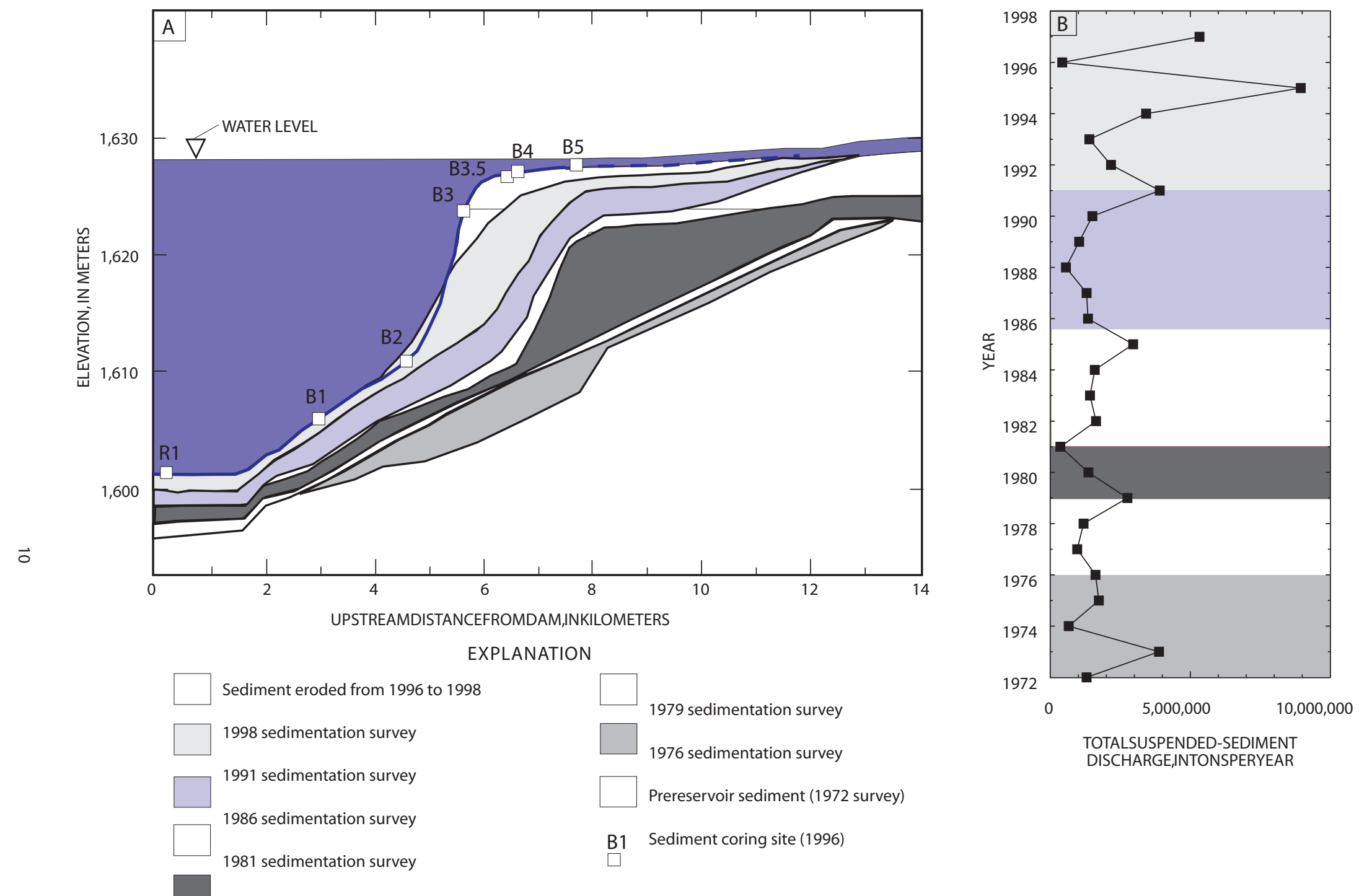

Figure 2. (A) Longitudinal profile of reservoir showing historical sedimentation and migration of sediment front. The upper surface of each deposit determined during the sedimentation surveys conducted by the U.S. Army Corps of Engineers. The sedimentsurface elevations calculated using data collected during the 1996 coring indicated by blue line. (B) Suspended-sediment discharge of the Rio Grande at Otowi Bridge, N. Mex. (U.S. Geological Survey streamflow-gaging station 08313000). 

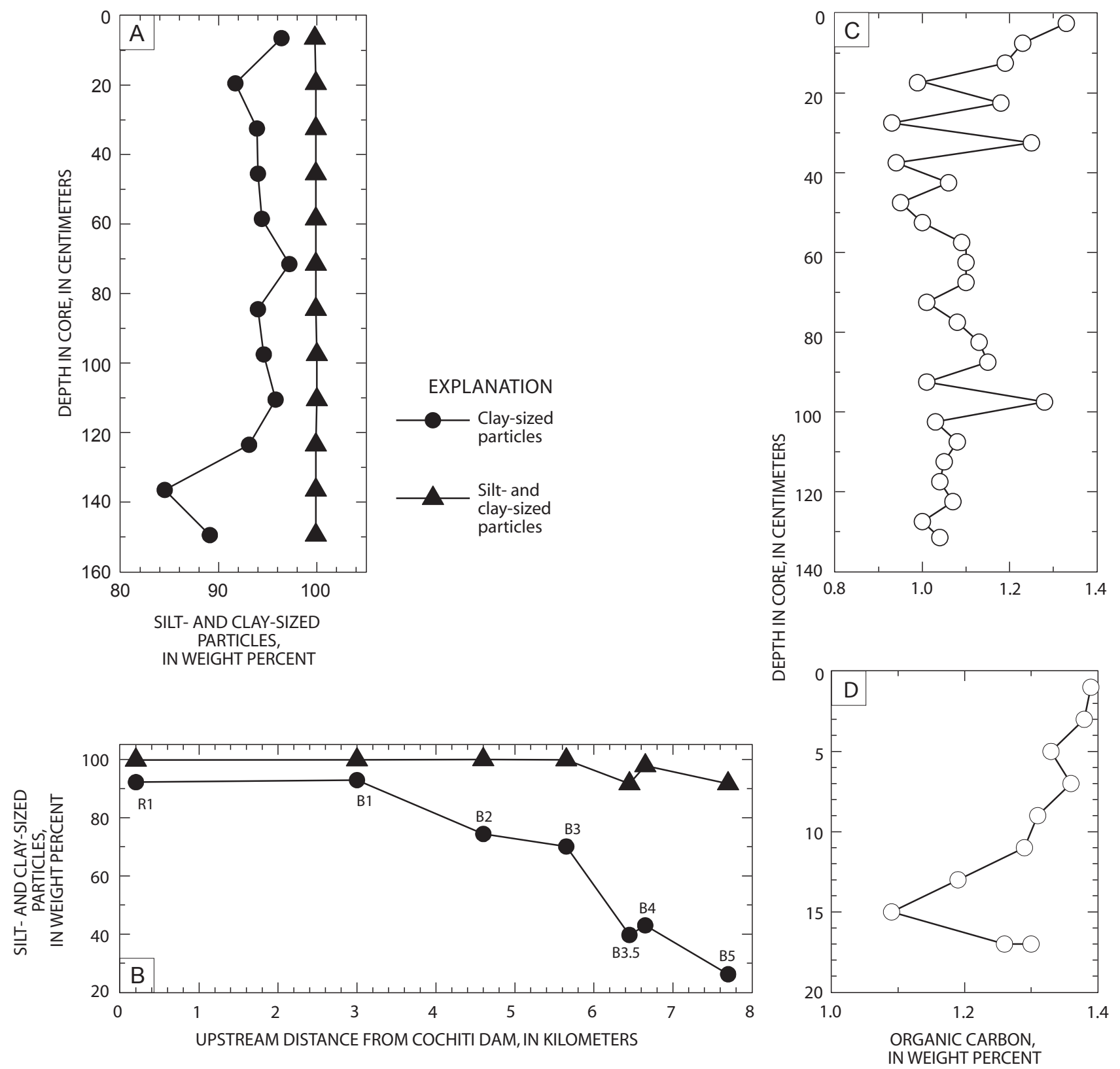

Figure 3. Grain size in a gravity core at site R1 (A) and box cores (B) and percentage of organic carbon in a gravity core (C) and box core at site R1 (D) from Cochiti Lake. 
Organic carbon was analyzed in a gravity core and box core from site R1. The percent organic carbon by weight ranged from 0.93 to 1.33 (fig. 3C), and the median was 1.07 percent in the full length of the gravity core. The box core from the same location had similar organic carbon concentrations as the corresponding upper portion of the gravity core. The box core concentrations ranged from 1.09 to 1.39 weight percent (fig. 3D), and the median was 1.31 percent. The weight percent organic carbon in the corresponding upper portion of the gravity core ranged from 0.99 to 1.33 (fig. 3C), and the median was 1.19. The percent organic carbon was greatest in the upper portion of both the gravity and box cores. The decrease in organic carbon just below the sediment-water interface is typical of subaqueous sediments and is a reflection of early diagenesis with burial (Froelich and others, 1979). The sediment intervals below $40 \mathrm{~cm}$ had relatively stable organic carbon values (with one exception at $97.5 \mathrm{~cm}$ ) (fig. 3C).

\section{Estimating Age of Sediments and Rates of Deposition}

Four of the five gravity cores penetrated to prereservoir material, as indicated by an abrupt transition from fine-grained (clay and silt), high watercontent sediment to a fine quartz sand with a low water content. The prereservoir boundary was at a mean depth of $138 \mathrm{~cm}$ and provides a date marker for 1975 , when the reservoir was impounded at the elevation of the permanent pool.

Initially, sediment deposition dates were to be calculated using variations in ${ }^{137} \mathrm{Cs}$ (half-life $=30.8$ years) and ${ }^{210} \mathrm{~Pb}$ (half-life $=22$ years) activities with depth in the gravity core analyzed for radionuclides.

However, the young age of Cochiti Lake limited their use, and deposition dates of core intervals were assigned on the basis of the average mass accumulation rate at site R1. Four of the five gravity cores collected at site R1 penetrated to prereservoir material, as indicated by an abrupt transition from fine-grained, high water-content sediment to a fine quartz sand with a low water content. The prereservoir boundary was at a mean depth of $138 \mathrm{~cm}$ and provides a date marker for 1975, when the reservoir was impounded at the elevation of the permanent pool. Because the sedimentation rate in Cochiti Lake has varied greatly since its impoundment (fig. 2), using the average mass accumulation rate makes the sediment deposition dates assigned approximate values. An average mass accumulation rate of 2.74 grams $(\mathrm{g}) / \mathrm{cm}^{2} / \mathrm{yr}$ was calculated for the gravity core analyzed for major and trace elements using the measured porosity of each sampling interval and an assumed density of solids of $2.5 \mathrm{~g} / \mathrm{cm}^{3}$. The approximate dates were then extrapolated to the equivalent depth intervals in the other cores on the basis of relative differences in core lengths. Porosity data were not available for the other cores to allow extrapolation by equivalent mass. An average linear sedimentation rate of $6.6 \mathrm{~cm} / \mathrm{yr}$ at site $\mathrm{R} 1$ was calculated using all five gravity cores.

The average mass accumulation rate of 2.74 $\mathrm{g} / \mathrm{cm}^{2} / \mathrm{yr}$ was calculated for the major and trace elements in the gravity core using measured porosity and an assumed density of solids of $2.5 \mathrm{~g} / \mathrm{cm}^{3}$. The dates were then extrapolated to the equivalent depth intervals in the other cores on the basis of relative differences in core lengths. An average linear sedimentation rate of $6.6 \mathrm{~cm} / \mathrm{yr}$ at site $\mathrm{R} 1$ was calculated using all five gravity cores.

\section{CHEMISTRY OF BOTTOM SEDIMENTS}

\section{Major Elements}

The concentrations of major elements at site R1 had little variability and showed no trends in the gravity core. Concentrations in the box core sediments also collected at site R1 were similar to those in the gravity core (fig. 4). An increase in concentrations of $\mathrm{Al}, \mathrm{Fe}$, $\mathrm{Mg}$, and $\mathrm{P}$ in the downstream direction was indicated by box cores collected along the length of the reservoir (fig. 5). $\mathrm{Ca}, \mathrm{K}$, and $\mathrm{Na}$ decreased in concentration toward Cochiti Dam. Horowitz and Elrick (1987) demonstrated that many inorganic elements associate with particles smaller than $0.063 \mathrm{~mm}$ in size, which is comparable to silt- and clay-sized particles as measured by the USGS sediment laboratory. The percentage of silt- and clay-sized particles has little variation in the box cores collected along the length of Cochiti Lake (fig. 3B). The concentrations of major elements were normalized with respect to grain size by dividing the elemental concentration by the percentage of silt- and clay-sized particles to check whether concentration variations along the length of the reservoir are associated with the small variation in grain size. Normalization does not affect concentration variations (fig. 5) and normalization of other inorganic elements (trace elements and radionuclides) was not considered to be necessary. 


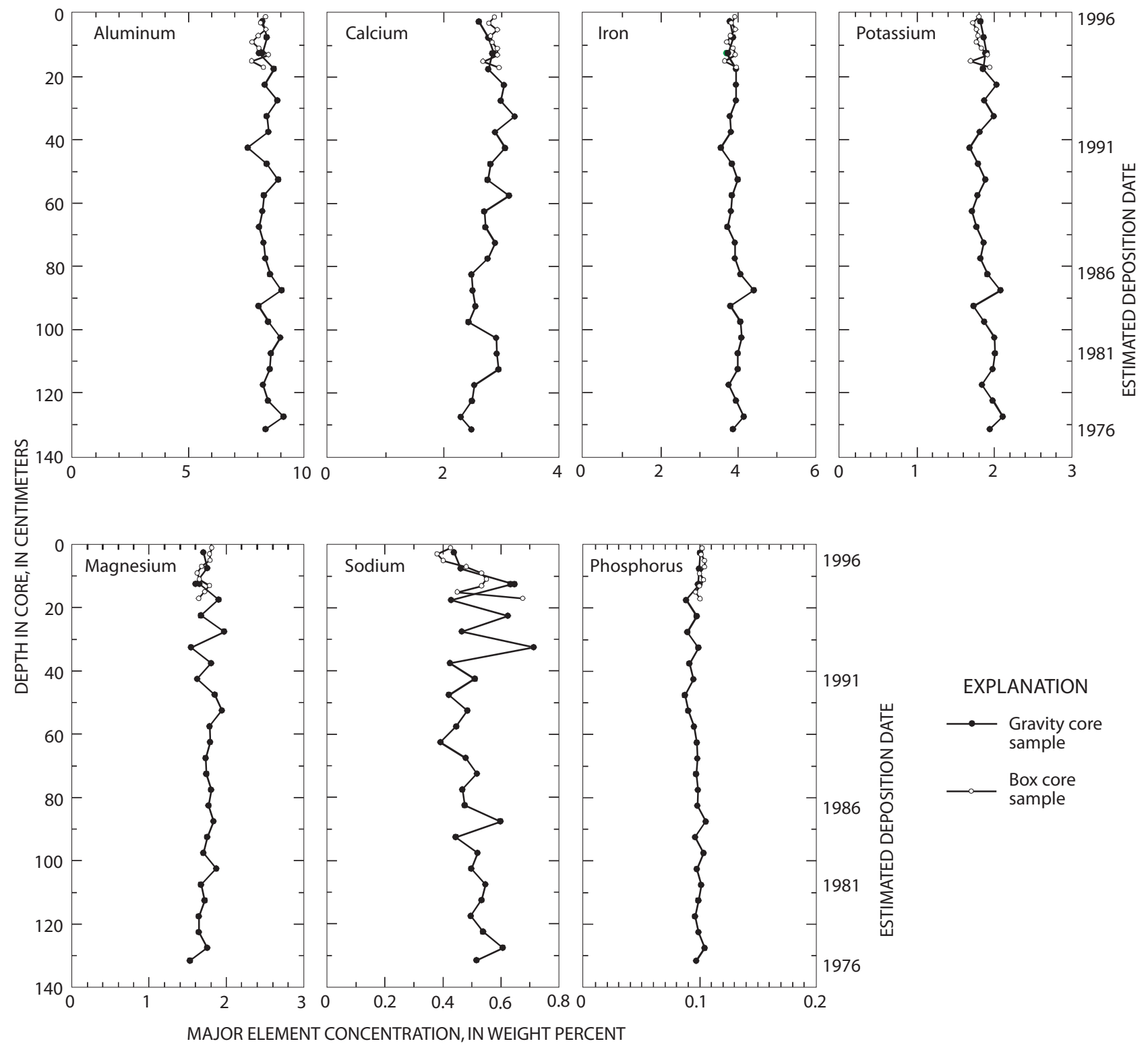

Figure 4. Major element concentrations in a gravity core and box core at site R1 from Cochiti Lake. 

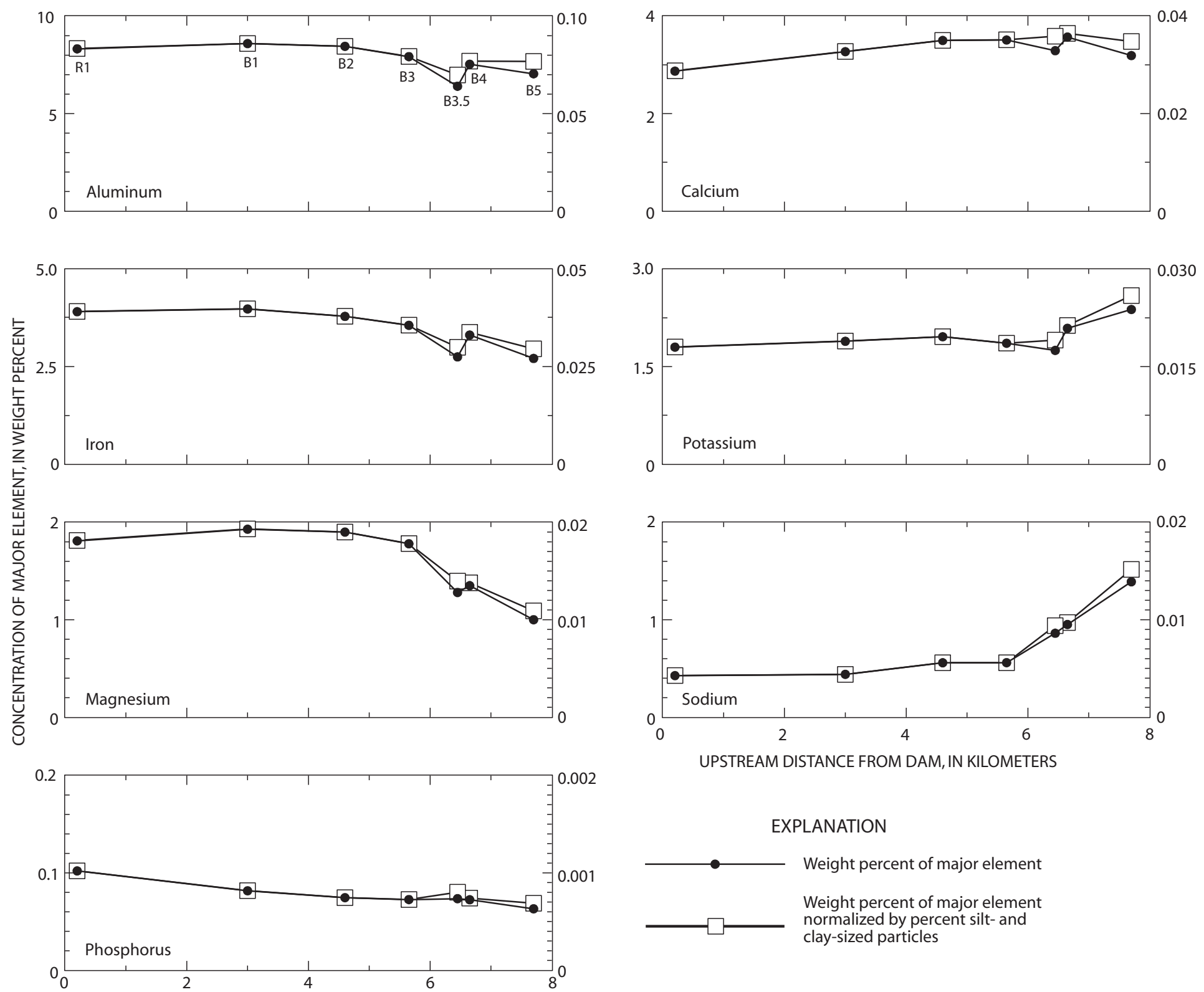

UPSTREAM DISTANCE FROM DAM, IN KILOMETERS

Figure 5. Major element concentrations in box cores from Cochiti Lake. Only the 0 - to 2-centimeter interval of box core R1 is shown. 


\section{Trace Elements}

Concentrations of $\mathrm{As}, \mathrm{Cr}, \mathrm{Cu}, \mathrm{Li}, \mathrm{Ni}$, and $\mathrm{Zn}$ showed small variations but no trends over their period of deposition in the gravity core from site R1. The concentrations of $\mathrm{Pb}$ and $\mathrm{Se}$ appear to have decreased with time (fig. 6); however, neither trend tested significantly at a 90-percent confidence interval (Spearman's rank correlation coefficient $=0.86$, $\mathrm{p}$ value $=<0.00001$ for lead; Spearman's rank correlation coefficient $=0.63$, $\mathrm{p}$-value $=0.00047$ for selenium).

Concentrations of $\mathrm{As}, \mathrm{Be}, \mathrm{Co}, \mathrm{Cr}, \mathrm{Cu}, \mathrm{Mn}, \mathrm{Ni}$, $\mathrm{Pb}, \mathrm{Se}$, and $\mathrm{Zn}$ increased in the downstream direction. Barium concentrations decreased toward Cochiti Dam and $\mathrm{U}$ concentrations were variable. The

concentrations of $\mathrm{Be}, \mathrm{Cr}, \mathrm{Li}, \mathrm{Mn}, \mathrm{Ni}$, and $\mathrm{U}$ at site $\mathrm{B} 3.5$ are noticeably lower than those at the adjacent box coring locations (fig. 7).

Table 4 compares trace-element concentrations in the Cochiti Lake gravity core to draft sedimentquality guidelines recommended by the Canadian Council of Ministers of the Environment (CCME) (1998) and Long and others (1995). Only elements that have guidelines are listed. These guidelines are not enforceable standards, but they provide a basis for comparison with the Cochiti Lake samples. The guidelines are based on numerous studies relating contaminant concentrations to measures of biological effects. CCME (1998) used a modification of the National Status and Trends Program approach to derive an interim sediment-quality guideline as the concentration below which adverse biological effects are rarely expected to occur. The probable-effect level was derived using the modified National Status and Trends Program approach and the spiked-sediment toxicity test approach to define the concentration above which adverse biological effects are expected to occur frequently (Canadian Council of Ministers of the Environment, 1998). Long and others (1995) separated concentrations whose "effects range-low" (ER-L) and "effects range-median" (ER-M). The 10th and 50th percentiles of concentrations associated with adverse biological effects, corresponding to ER-L and ER-M, respectively, define the guidelines.

The concentration ranges of $\mathrm{As}, \mathrm{Cr}, \mathrm{Cu}, \mathrm{Pb}, \mathrm{Ni}$, and $\mathrm{Zn}$ in the gravity core are at or above thresholdeffect levels of at least one of the sediment-quality guidelines. All trace-element concentrations are below the probable-effect level. Although some of these concentrations are above threshold-effect levels, there is no evidence from this study that trace-element concentrations have been affected by anthropogenic activities.

\section{Organochlorine Compounds}

The organochlorine compounds detected in Cochiti Lake sediments include PCB's and DDT and its metabolites DDD and DDE. Thirteen other organochlorine compounds were analyzed for but not detected, including chlordane and dieldrin (table 1). Organochlorine compounds are persistent in the environment, have low water solubility, and sorb strongly to particulate matter. Octanol-water partition coefficients for PCB's, DDT, DDD, and DDE range from $10^{5}$ to $10^{6}$ (Smith and others, 1988), indicating that these compounds will strongly partition into sediment organic matter. The octanol-water partition coefficient of a compound is the ratio of the compound's concentration in a known volume of $n$ octanol to its concentration in a known volume of water after equilibrium is reached (Smith and others, 1988). These compounds have been shown to be highly resistant to chemical breakdown in the natural environment (Smith and others, 1988; Alder and others, 1993) and are frequently detected in lake (Eisenreich and others, 1989) and reservoir (Van Metre and others, 1998) sediment cores.

\section{Polychlorinated Biphenyls (PCB's)}

PCB's were first synthesized in the laboratory in 1929, and an estimated $5.94 \times 10^{8}$ kilograms $(\mathrm{kg})$ were produced from 1930 to 1974 (National Academy of Sciences, 1979). Annual PCB sales in the United States peaked at 36,530 metric tons in 1970 and declined to about one-half that amount by 1975 following the 1971 voluntary ban on PCB use in open systems (Peakall, 1975). In 1979 all new uses of PCB's were banned (National Academy of Sciences, 1979). PCB's were formulated and sold as Aroclors, which are complex mixtures of individual PCB compounds known as congeners. The analytical method used for this study quantified PCB's relative to three Aroclor standards (Aroclor 1242, Aroclor 1254, and Aroclor 1260) (Wershaw and others, 1987).

Cochiti Lake was constructed a few years before the complete ban on PCB usage. However, PCB capacitors and transformers were still in use at LANL in 1993, and numerous PCB-contaminated items were in storage on the facility (Los Alamos National Laboratory, 1995, p. III-13). One or more Aroclors were detected in 7 of 10 samples from the gravity core from site R1 (table 5) and in 3 of 7 box core samples; 

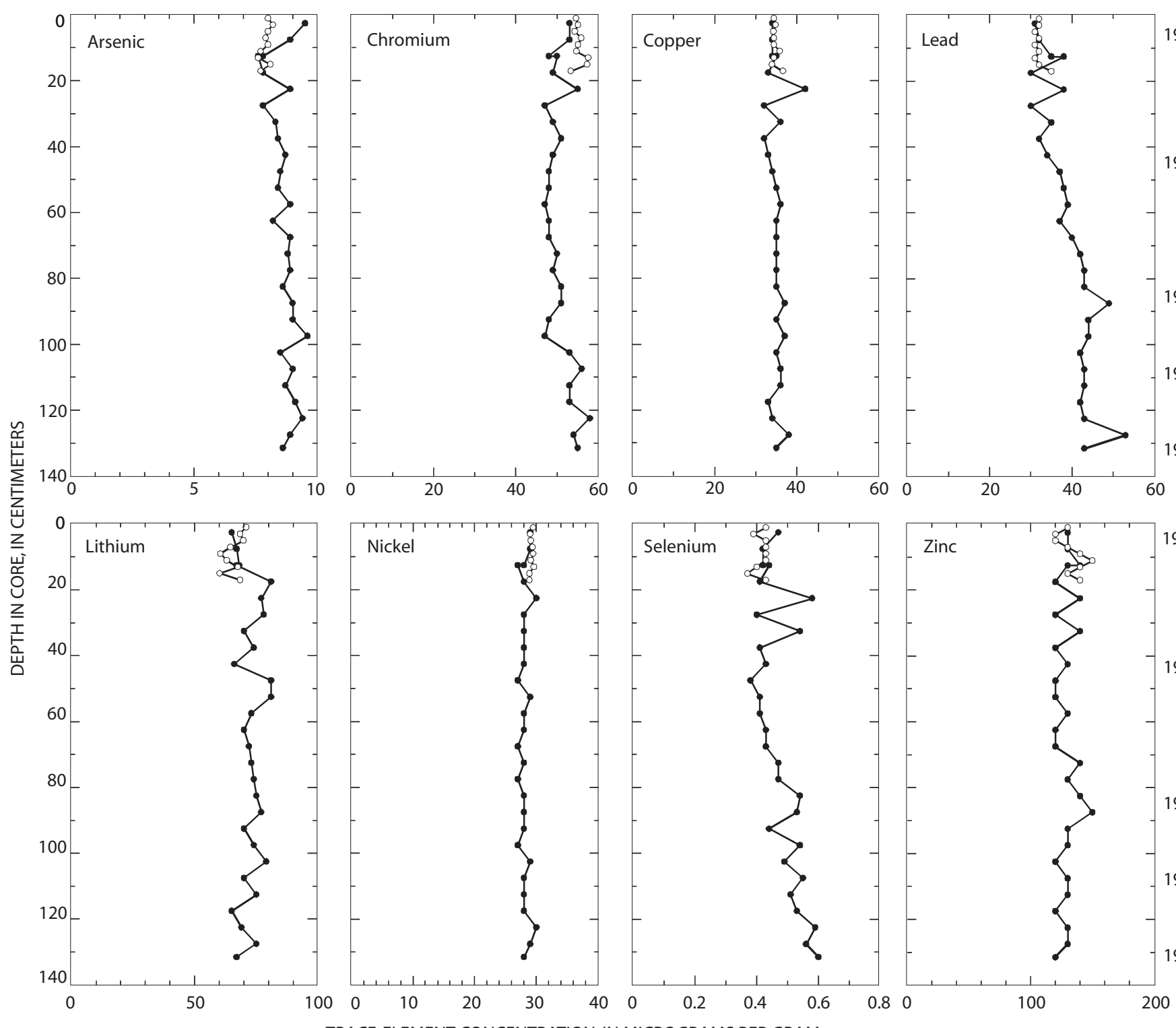

1996
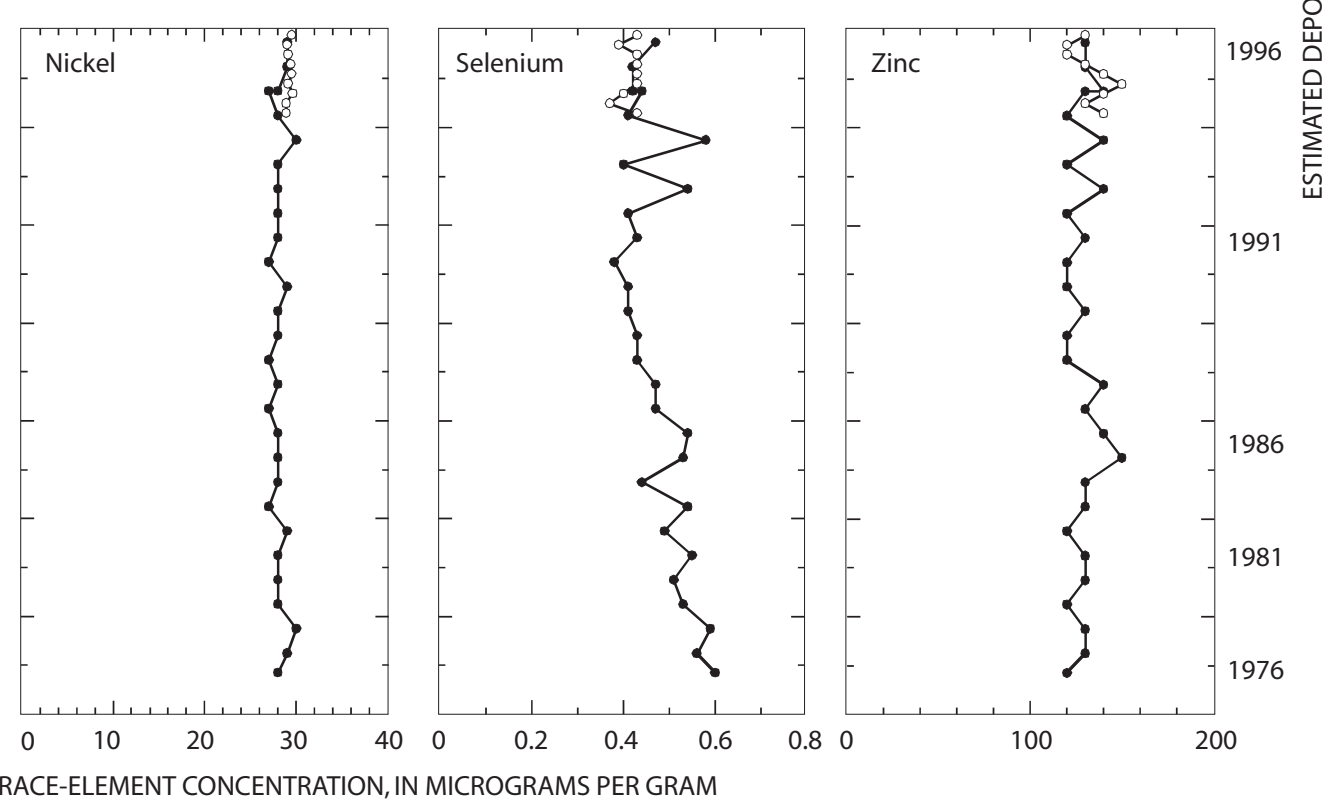

TRACE-ELEMENT CONCENTRATION, IN MICROGRAMS PER GRAM

EXPLANATION

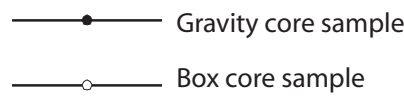

Figure 6. Trace-element concentrations in a gravity core and box core at site R1 from Cochiti Lake. 

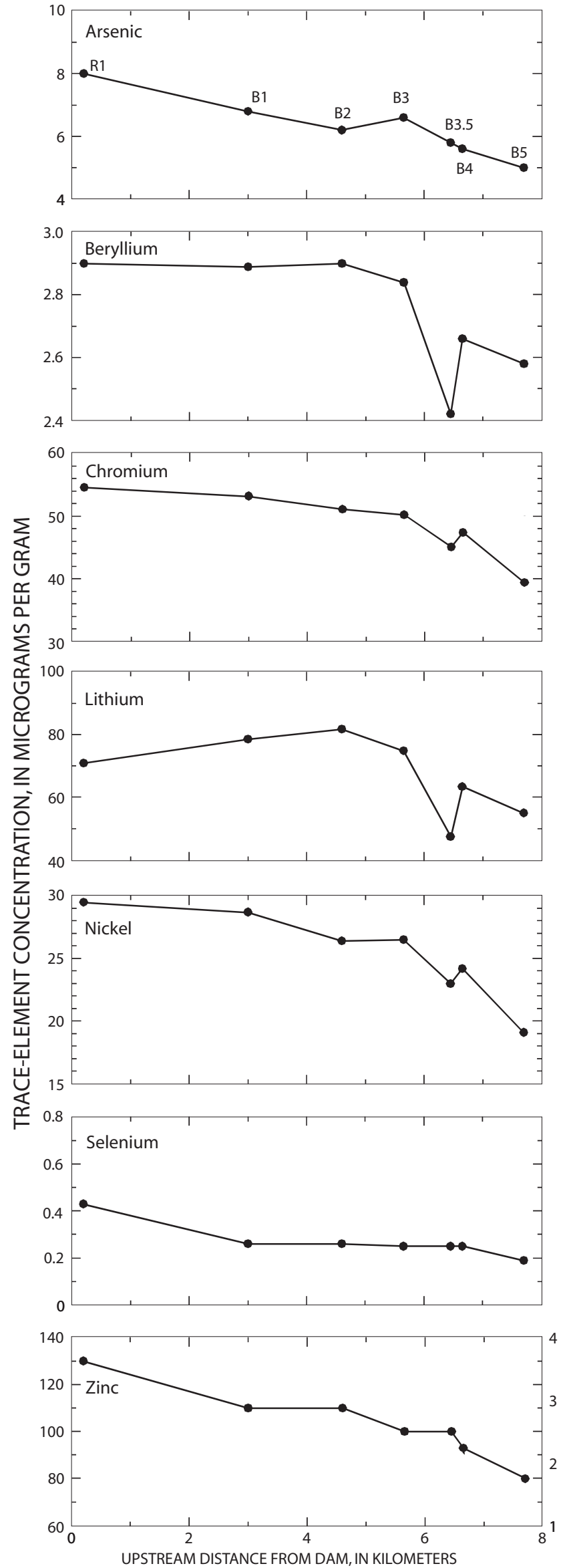
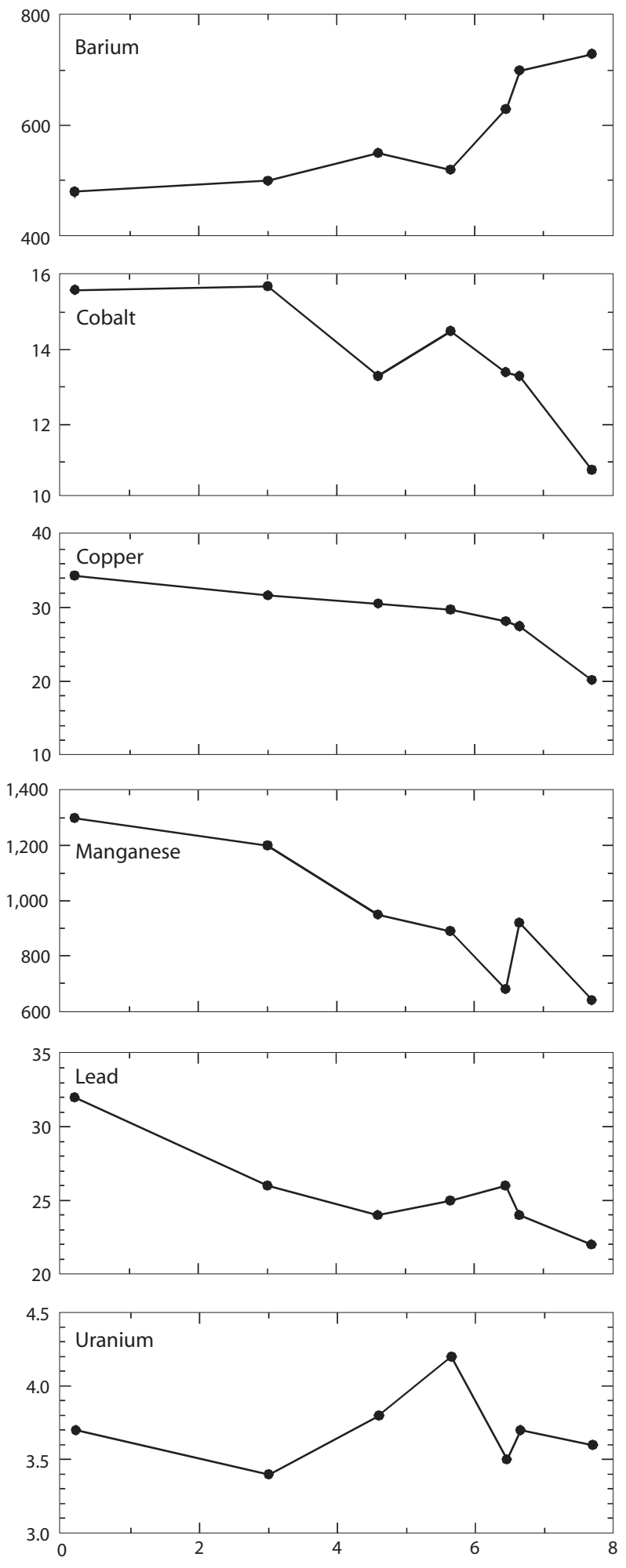

UPSTREAM DISTANCE FROM DAM, IN KILOMETERS

EXPLANATION

Trace-element concentration

Figure 7. Trace-element concentrations in box cores from Cochiti Lake. Only the 0- to 2-centimeter interval of box core $\mathrm{R} 1$ is shown. 
Table 4. Trace-element sediment-quality guidelines compared to concentration ranges, in micrograms per gram, in Cochiti Lake gravity core

[CCME, Canadian Council of Ministers of the Environment; ISQG, interim sediment-quality guideline; PEL, probable-effect level; --, no guidelines defined; ER-L, effects range-low;

ER-M, effects range-median; median values are in parentheses]

\begin{tabular}{lcccccccc}
\hline \multicolumn{1}{c}{$\begin{array}{c}\text { Sediment- } \\
\text { quality } \\
\text { guideline }\end{array}$} & Arsenic & Cadmium & $\begin{array}{c}\text { Chro- } \\
\text { mium }\end{array}$ & Copper & Lead & Nickel & Zinc \\
\hline CCME & ISQG & 5.9 & 0.6 & 37.3 & 35.7 & 35.0 & -- & 123 \\
$(1998)$ & PEL & 17.0 & 3.5 & 90.0 & 197 & 91.3 & -- & 315 \\
& LR-L & 8.2 & 1.2 & 81 & 34 & 46.7 & 20.9 & 150 \\
$\begin{array}{l}\text { Long and } \\
\text { others }\end{array}$ & ER-M & 70 & 9.6 & 370 & 270 & 218 & 51.6 & 410 \\
\multicolumn{2}{c}{ Cochiti Lake } & $7.6-9.6$ & $0.3-0.5$ & $47-58$ & $32-42$ & $30-53$ & $27-30$ & $120-150$ \\
& $(8.8)$ & $(0.4)$ & $(50)$ & $(35)$ & $(40)$ & $(28)$ & $(130)$ \\
\hline
\end{tabular}

Table 5. Concentrations of polychlorinated biphenyls (PCB's), in micrograms per kilogram, in Cochiti Lake gravity core from site R1 and box cores from all sites

[cm, centimeters; E, estimated; <, less than]

\begin{tabular}{|c|c|c|c|c|}
\hline Sample name & Middepth (cm) & Aroclor 1242 & Aroclor 1254 & Aroclor 1260 \\
\hline \multicolumn{5}{|c|}{ Gravity core } \\
\hline COC.1 0-12 & 6 & E1.9 & $<2.0$ & $<2.0$ \\
\hline COC.1 12-24 & 18 & 2.4 & $<2.0$ & $<2.0$ \\
\hline COC.1 24-36 & 30 & $<3.0$ & $<3.0$ & $<3.0$ \\
\hline COC.1 36-48 & 42 & $<2.5$ & $<2.5$ & $<2.5$ \\
\hline COC. $148-60$ & 54 & 2.2 & $<2.0$ & $<2.0$ \\
\hline COC.1 60-72 & 66 & 2.2 & $<2.0$ & $<2.0$ \\
\hline COC.1 72-84 & 78 & 1.4 & 1.2 & 1.2 \\
\hline COC.1 84-96 & 90 & E0.97 & E0.96 & 1.3 \\
\hline COC.1 96-108 & 102 & 1.2 & 1.1 & 1.0 \\
\hline COC.1 108-120 & 114 & $<2.0$ & $<2.0$ & $<2.0$ \\
\hline \multicolumn{5}{|c|}{ Box cores } \\
\hline COC.R1 & 2.5 & 2.2 & $<2.0$ & $<2.0$ \\
\hline COC.B1 & 2.5 & $<2.0$ & $<2.0$ & $<2.0$ \\
\hline COC.B2 & 2.5 & $<2.0$ & $<2.0$ & $<2.0$ \\
\hline COC.B3 & 2.5 & $<1.0$ & $<1.0$ & $<1.0$ \\
\hline COC.B3.5 & 2.5 & 1.3 & 1.7 & $<1.0$ \\
\hline COC.B4 & 2.5 & 1.5 & $<1.0$ & $<1.0$ \\
\hline COC.B5 & 2.5 & $<1.0$ & $<1.0$ & $<1.0$ \\
\hline
\end{tabular}


all were at very low levels, however. Since completion of this study, the USGS NWQL has raised the reporting level for PCB Aroclors to 5.0 micrograms per kilogram $(\mu \mathrm{g} / \mathrm{kg}$ ) because of a change of equipment (Brooke Connor, U.S. Geological Survey, written commun., 1997), which is greater than all detections in Cochiti Lake.

Aroclor 1242 was the most commonly detected PCB in the gravity core ( 7 of 10 intervals). Aroclor 1254 and 1260 had detectable concentrations in three sediment intervals deposited in the early 1980's. Aroclor 1242 and 1254 were detected in three and one box cores, respectively (table 5). The maximum concentration of total PCB's (the sum of Aroclors 1242, 1254, and 1260) detected in Cochiti Lake sediments is well below sediment-quality guidelines (table 6). The magnitude of PCB concentrations and comparison to sediment-quality guidelines indicate that Cochiti Lake sediments are relatively uncontaminated with PCB's. Cochiti Lake PCB concentrations are similar to those in other Rio Grande reservoirs (Van Metre and others, 1996a) and smaller than concentrations reported for urban reservoirs in Texas and Georgia (Van Metre and others, 1997).

\section{DDT, DDD, and DDE}

The organochlorine pesticide DDT was first synthesized in 1874 and was used as an insecticide beginning in 1939 (U.S. Environmental Protection Agency, 1983). DDT usage peaked in the United States in the early 1960's (Rapaport and others, 1985). Wide use of DDT on cotton, fruits, and vegetables continued in the United States until about 1970. DDT use was banned nationwide in 1972 (Smith and others, 1988). Occurrences of DDT and its metabolites, DDD and DDE, are common in reservoir bottom sediments (Van Metre and others, 1997). Agricultural and urban activities upstream from Cochiti Lake could have contributed DDT to the watershed.

DDD and DDE were present in all sediment intervals in the gravity core collected at site R1 (fig. 8A). DDE had larger concentrations than DDD and DDT, composing 52 to 69 percent of total DDT (DDD $+\mathrm{DDE}+\mathrm{DDT})$. Concentrations of DDT were detected in 6 of the 10 sediment intervals. Concentrations of DDD, DDE, and total DDT have statistically significant decreasing trends in the sediment deposited from about 1980 to 1992 (Spearman's rank correlation coefficient $=0.93, \mathrm{p}$-value $=0.00086$ for DDD and DDE; Spearman's rank correlation coefficient $=0.90$, $\mathrm{p}$-value $=0.00201$ for total DDT). The trends indicated by samples deposited from about 1980 to 1992 are similar to total DDT trends observed in many reservoirs (Van Metre and others, 1998) and lakes (Eisenreich and others, 1989). These metabolites have increased slightly from 1992 to the present. This increase could partly be the result of slightly higher organic carbon concentrations near the top of the core (fig. 3C); however, normalizing DDD and DDE to organic carbon does not reverse this trend. The recent increase also could result from the redistribution of sediments within the reservoir containing higher total DDT concentrations. Larger total DDT concentrations in two of the box core samples from the upstream part of the reservoir (sites B3.5 and B4, fig. 8B) suggest that this is possible.

DDD, DDE, and DDT were detected in all box core samples (fig. 8B). As with the gravity core, DDE had the largest concentrations, composing 56 to 66 percent of total DDT. DDD and DDT had similar concentrations. Concentrations of total DDT were largest at the box coring location B4. Sites B3.5 and B4 had greater total DDT and DDE values than those in the gravity core. These box cores were collected along the sediment front where the water depth changes from shallow, riverlike conditions to deep, lakelike conditions. A large portion of the sediment load carried by the Rio Grande drops out of suspension here as the water becomes deeper and the flow velocity slows. The deposition of sediment and associated sediment-bound contaminants in this area may contribute to the elevated total DDT concentrations at box coring locations B3.5 and B4. Total DDT concentrations in these two samples (3.23 and $4.53 \mu \mathrm{g} / \mathrm{kg}$, respectively) are below threshold-effect levels (table 6). As was the case for PCB's, total DDT concentrations in Cochiti Lake sediments are similar to those in other Rio Grande reservoirs for comparable time intervals (Van Metre and others, 1996a) and smaller than those in urban and agricultural reservoirs in Texas and Georgia (Van Metre and others, 1997). 
Table 6. Organic sediment-quality guidelines compared to concentration ranges, in micrograms per gram, in Cochiti Lake gravity core

[CCME, Canadian Council of Ministers of the Environment; ISQG, interim sediment-quality guideline, PEL, probable-effect level. --, no guidelines defined. ER-L, effects range-low. ER-M, effects range-median. $<$, less than. Median values are in parentheses]

\begin{tabular}{cccccc}
\hline Agency & $\begin{array}{c}\text { Sediment- } \\
\text { quality } \\
\text { guideline }\end{array}$ & Total PCB & Total DDT & $\begin{array}{c}\text { Benz(a)- } \\
\text { anthracene }\end{array}$ & $\begin{array}{c}\text { Benzo(a)- } \\
\text { pyrene }\end{array}$ \\
\hline CCME & ISQG & 34.1 & 6.2 & 31.7 & 31.9 \\
$(1998)$ & PEL & 277 & 20.0 & 385 & 782 \\
$\begin{array}{c}\text { Long and others } \\
\text { (1995) }\end{array}$ & ER-L & 23 & 1.6 & -- & -- \\
Cochiti Lake & ER-M & 180 & 46 & -- & -- \\
& & $<3.8-6.2$ & $1.12-2.56$ & $1.64-7.75$ & $1.74-10.2$ \\
& & $(<6.1)$ & $(2.00)$ & $(2.43)$ & $(2.95)$ \\
& & & & & \\
Agency & Sediment- & & & & \\
\hline CCME & quality & Fluoran- & Phenan- & & (thene \\
guideline & threne & Pyrene & Total PAH \\
\hline Long and others & ISQG & 111 & 41.9 & 53.0 & \\
$(1995)$ & PEL & 2,355 & 515 & 875 & \\
Cochiti Lake & ER-L & -- & -- & -- & 4,000 \\
& ER-M & -- & -- & -- & 45,000 \\
& & $4.64-12.8$ & $2.91-11.3$ & $4.38-13.8$ & $134-240$ \\
& & $(7.46)$ & $(5.40)$ & $(6.82)$ & $(190)$ \\
\hline
\end{tabular}

\section{Polycyclic Aromatic Hydrocarbons}

PAH's are a group of organic compounds composed of two or more fused benzene rings with hydrogen atoms attached and side chains of alkyl groups possible. These chemicals are very hydrophobic, relatively unreactive, and sorb strongly to sediments. PAH's are formed through pyrolysis (high temperature) reactions during the burning of wood, coal, oil, and petroleum products, and occur in uncombusted oil and petroleum products as well. They have both anthropogenic and natural sources, which include emissions from vehicles, power plants, and residential heating devices; used crankcase oil; crude oil; and forest fires. Some PAH's are carcinogenic and (or) toxic to humans and aquatic life through multiple exposure pathways (Harvey, 1991). Concentrations of PAH's increased in the environment during the 20th century in response to increased burning of fossil fuels (Hites and others, 1981). Urban areas, recreational areas, LANL, and forest fires within the watershed of Cochiti Lake could be historical contributors of PAH's to the sediments stored in the reservoir.

Sixty-one PAH's were analyzed for in the bottom sediments of Cochiti Lake. Fifteen of the 23 parent PAH's and 17 of the 38 alkyl-homologs were detected in one-half or more of the gravity core samples (table 2). Naphthalene alkyl-homologs containing one or two alkyl groups (C1-128 and C2-128 isomers, respectively) had the highest concentrations, with the exception of perylene, and were detected in 16 of 17 samples from both the gravity and box cores. Alkylhomologs of phenanthrene/anthracene (C1-178 and C2-178 isomers) and fluoranthene/pyrene (C1-202 isomers) also have high concentrations relative to the other PAH compounds. The concentration of perylene in the gravity core is especially high compared to other compounds. Perylene, though, is believed to form in place (LaFlamme and Hites, 1978) and is not considered a PAH contaminant from the drainage area. 

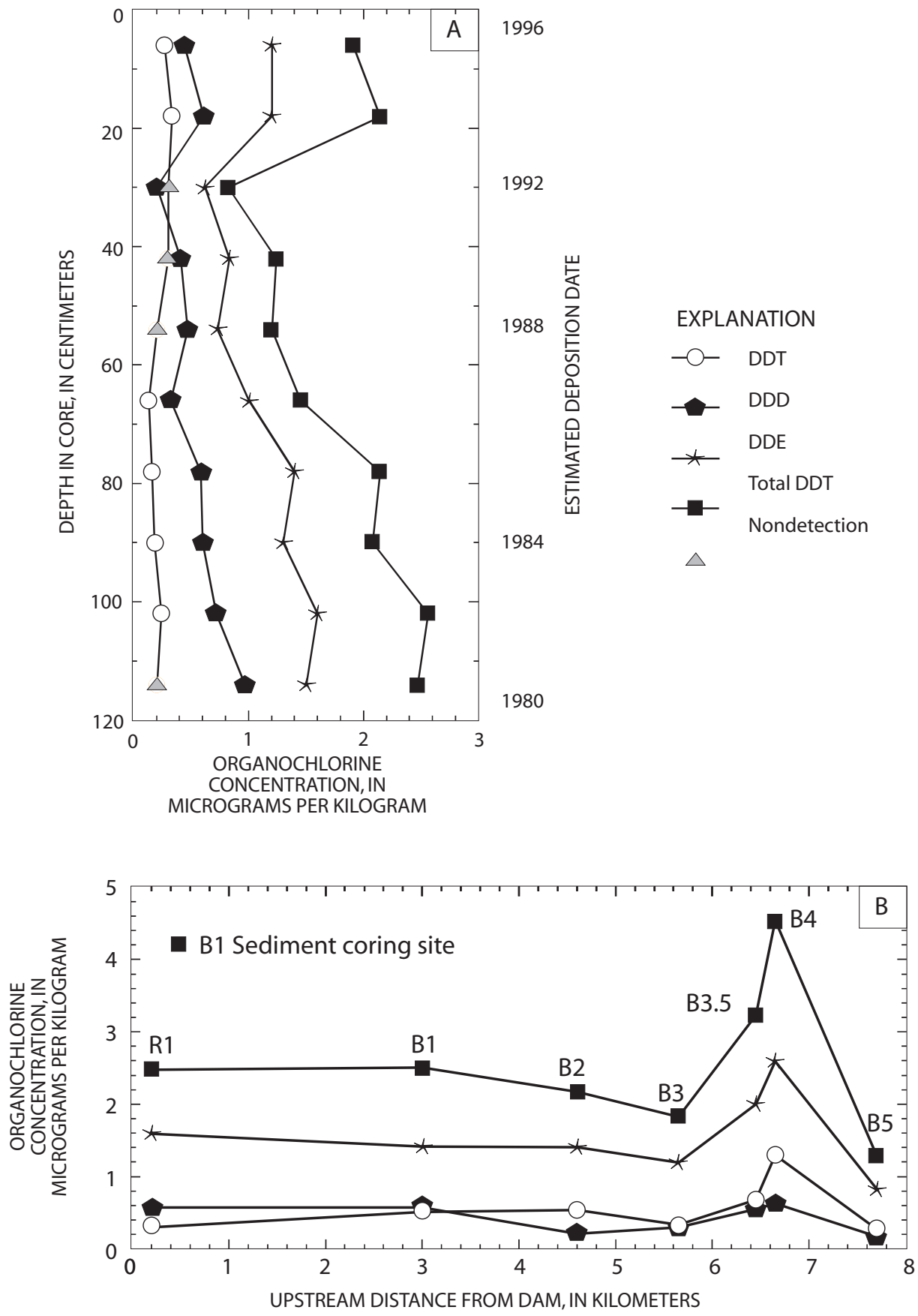

Figure 8. Concentrations of DDT and its metabolites in a gravity core (A) and box cores (B) from Cochiti Lake. 
PAH's with the largest concentrations and the most detections in both the gravity core and box cores are shown in figures 9 and 10. The dominant compounds in the gravity core, naphthalenes with two alkyl groups (C2-128 isomers), have a statistically significant increasing trend in the sediments deposited since about $1988(54 \mathrm{~cm})$ (Spearman's rank correlation coefficient $=-0.90, \mathrm{p}$-value $=0.037)$. The other compounds most commonly detected had elevated concentrations in the early 1990's relative to adjacent sample intervals (fig. 9A-D). Total PAH is the sum of all PAH compound concentrations (parent and alkylhomologs excluding perylene) measured in each sample. The amount of total PAH generally increased up to the most recently deposited sediments (fig. 9E). The amount of total PAH appears to increase with time (fig. 9E); however, this trend is not statistically significant (Spearman's rank correlation coefficient $=$ 0.73 , p-value $=0.024$ for all except the bottommost sample).

Sediment-quality guidelines are available for five parent PAH's and total PAH, none of which are exceeded by Cochiti Lake gravity core samples (table 6). In fact, PAH concentrations in Cochiti Lake sediments are about two to four orders of magnitude smaller than those in urban lakes and reservoirs in Texas, Virginia, and Minnesota measured using the same methods as in this study (unpublished data).

The mixture of PAH compounds varies for PAH's from different sources. Fuels (for example, crude oil) generally contain proportionally more low molecular weight (two and three ringed) PAH's and more alkylated homologs than combustion products do (Hites and others, 1981; Eganhouse and Gossett, 1991). Conversely, combustion products are enriched in higher molecular weight parent PAH's. Naphthalene and its alkylated homologs (two-ringed compounds) compose the greatest percentage of total PAH in the Cochiti Lake gravity core. This group accounts for 31 to 57 percent of total PAH in the core (fig. 9E).

Various ratios of PAH's have been used to evaluate sources of PAH's to lake sediments (Hites and others, 1981). One such indicator is the ratio of the sum of 2- and 3-ringed PAH's to the sum of combustion PAH's. The sum of combustion PAH's includes nine non-alkylated compounds (fluoranthene, pyrene, benz(a)anthracene, chrysene, benzofluoranthenes, benzo(e)pyrene, benzo(a)pyrene, benzo(g,h,i)perylene, and indeno(1,2,3-c,d)pyrene) that commonly contribute to PAH mixtures derived from the high- temperature burning of fuels (Prahl and Carpenter, 1983). The ratio of the sum of 2- and 3-ringed PAH to the sum of combustion PAH's decreases as combustion PAH's become more dominant, often an indication of increased vehicle emissions. This ratio is larger than unity for sediments in the gravity core, ranging from 1.4 to 4.4 , and increases in the top portion of the core (fig. 9F). Ratio values greater than unity indicate that the PAH mixture does not have high-temperature combustion processes as its dominant source. Uncombusted fuels or lower temperature combustion processes may be contributing more to this mixture. Uncombusted fuels as the dominant source of PAH's to the sediments is also indicated by the dominance of alkylated two-ringed compounds, such as napthalene and its alkylated homologs. In addition, PAH mixtures produced by the burning of wood and brush are dominated by benzo(a)pyrene and coronene (Freeman and Cattell, 1990), two compounds that do occur but are not prevalent in Cochiti Lake sediments. The peak in selected parent PAH's, such as fluoranthene, pyrene, and chrysene, in about 1990 coincides with a low ratio of 2- and 3-ringed to combustion PAH's, indicating a greater proportion of combustion sources in this part of the core.

The concentrations of the same $10 \mathrm{PAH}$ compounds discussed for the gravity core do not exhibit a consistent spatial pattern for the box cores (fig. 10A-D). Several low molecular weight and alkylhomolog compounds had peak concentrations at site B4 (fig. 10A, B), which was similar to the DDT pattern (fig. 8B) and may be associated with the sediment front. The concentrations of the 4- and 5-ringed compounds and C2-128 isomers increased in the downstream direction (fig. 10A, C, D). Total PAH concentrations ranged from 245 (site B5) to $654 \mu \mathrm{g} / \mathrm{kg}$ (site B4, fig. 10E). All concentrations of PAH's in box core sediments are below the sediment-quality guidelines shown in table 6 .

The ratio of the sum of 2- and 3-ringed compounds to sum of combustion PAH's decreased in the downstream direction (fig. 10F). Higher ratios in the upper reservoir indicate the dominance of fuelrelated sources; decreases in the lower part of the reservoir indicate a relative increase in combustion sources. Regardless, the ratio remains larger than unity along the length of the reservoir, indicating fuel-related sources as the dominant contributors of PAH's to the surficial sediments in Cochiti Lake. Chemical differences in individual PAH's may also affect this 

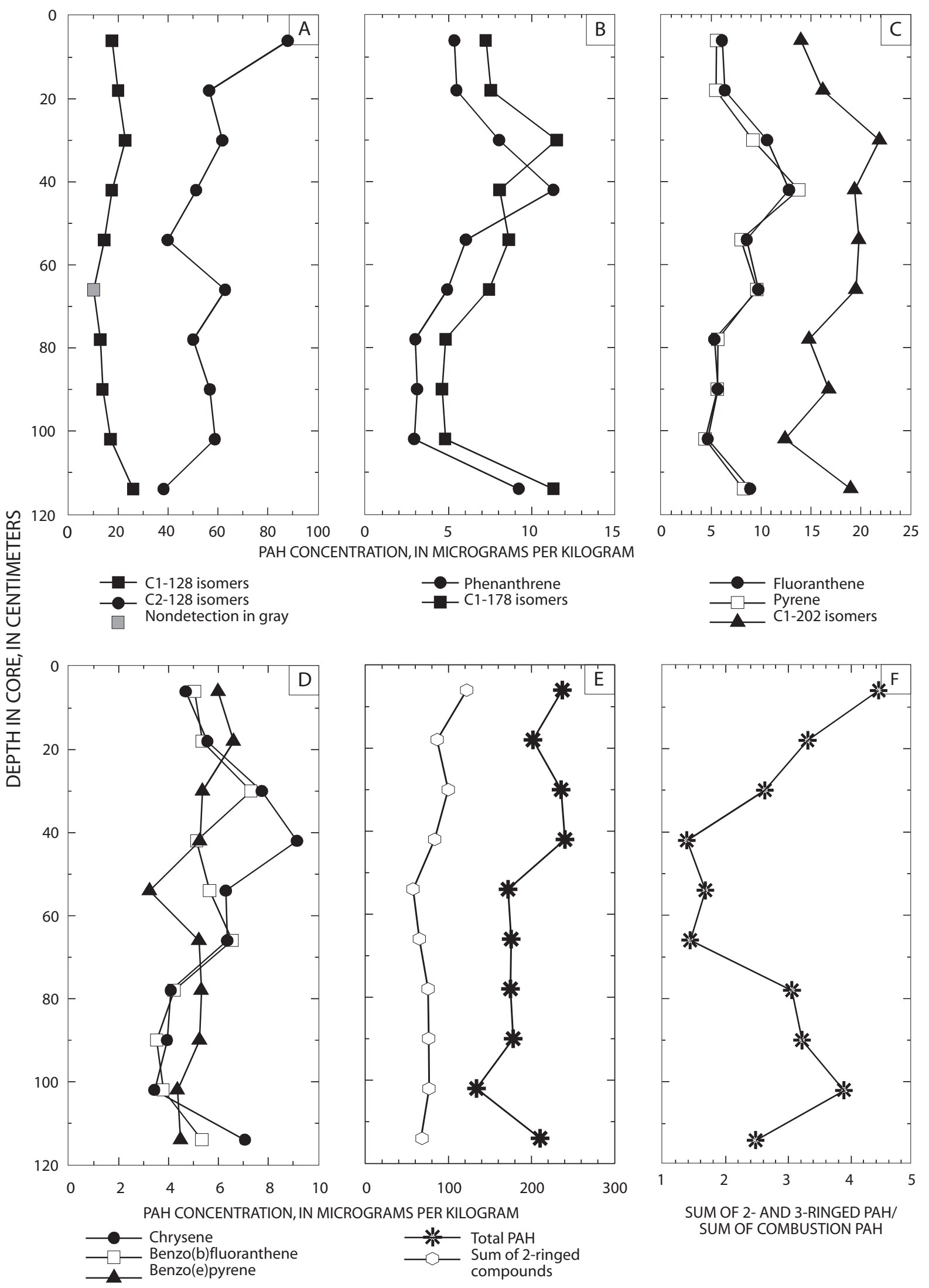

1996

1992

1988

1984

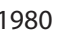

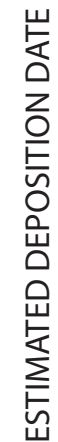

1992

1988

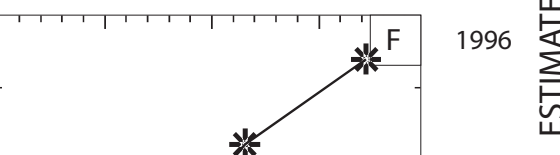

1984

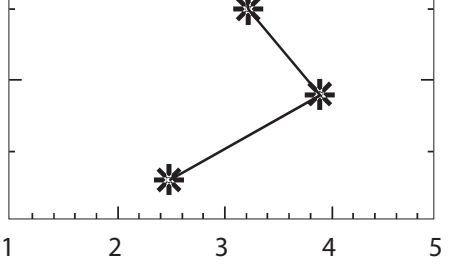

1980

SUM OF 2- AND 3-RINGED PAH/ SUM OF COMBUSTION PAH

Figure 9. Polycyclic aromatic hydrocarbon (PAH) concentrations (A-D), PAH sums (E), and the ratio of the sum of 2- and 3-ringed PAH's to total combustion PAH $(F)$ in a gravity core from Cochiti Lake. 

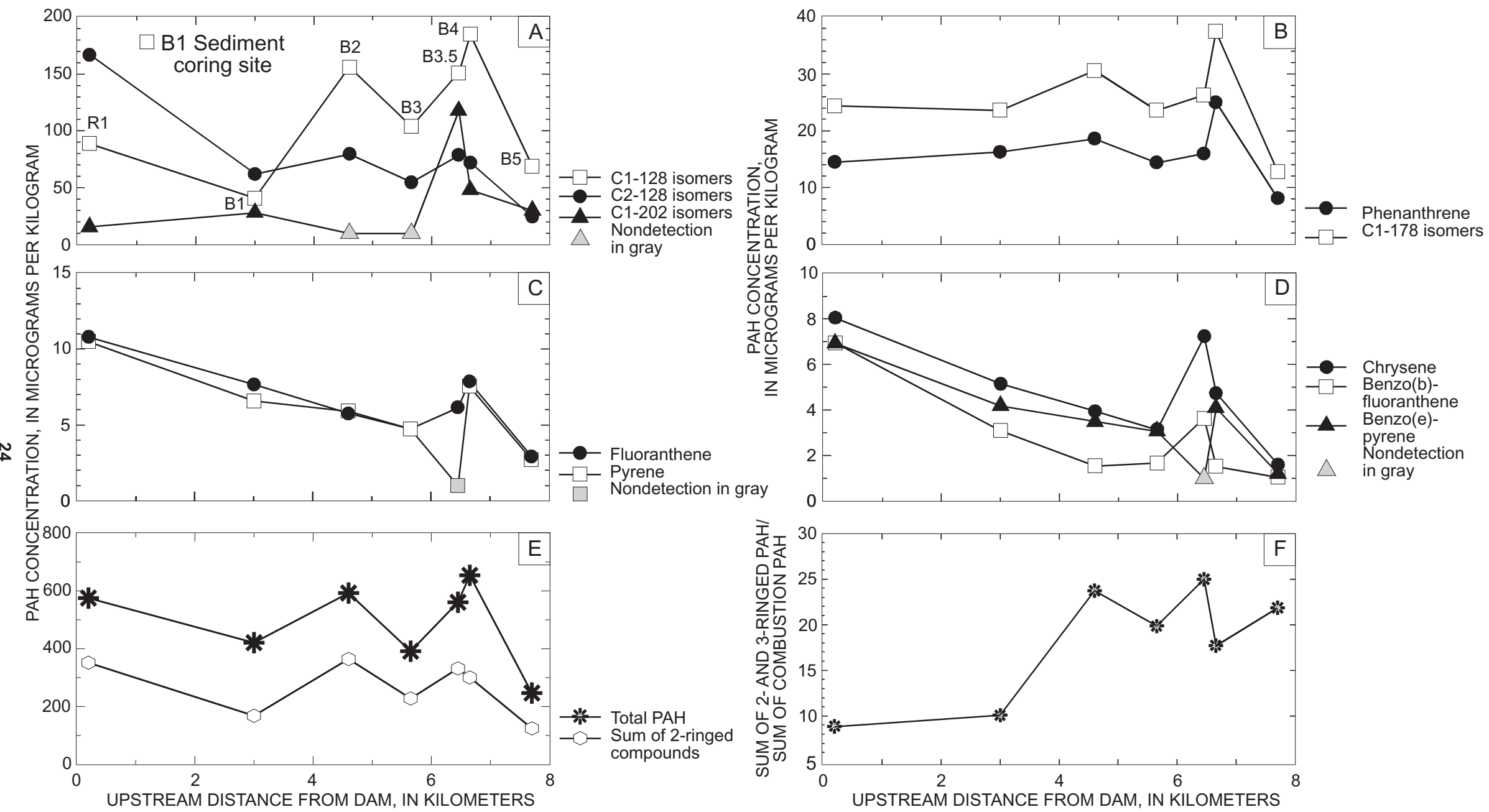

Figure 10. Polycyclic aromatic hydrocarbon (PAH) concentrations (A-D), PAH sums (E), and the ratio of the sum of 2- and 3-ringed PAH's to total combustion PAH $(F)$ in box cores from Cochiti Lake. Box core sampling locations are labeled above data points in $(A)$. 
ratio. One chemical factor that could affect this pattern is that the lower molecular weight PAH's (2- and 3ringed compounds) have greater water solubilities than higher molecular weight PAH's (Lucius and others, 1992; Knox and others, 1993). Thus, a decrease in this ratio downstream could be caused by the preferential leaching of these lower molecular weight compounds as sediments are (gradually) transported downstream.

\section{Radionuclides}

Ten radionuclides were analyzed for in the bottom sediments from Cochiti Lake. The radionuclides are ${ }^{137} \mathrm{Cs},{ }^{210} \mathrm{~Pb},{ }^{226} \mathrm{Ra},{ }^{234} \mathrm{U},{ }^{235} \mathrm{U}$, ${ }^{238} \mathrm{U},{ }^{230} \mathrm{Th},{ }^{232} \mathrm{Th},{ }^{238} \mathrm{Pu}$, and ${ }^{239,240} \mathrm{Pu}$. Uranium$234,{ }^{235} \mathrm{U}$, and ${ }^{238} \mathrm{U}$ were found at all depth intervals in the gravity core (fig. 11A, B). Uranium-234 and ${ }^{238} \mathrm{U}$ have similar activities, ranging from 1.14 to 1.56 and 1.19 to 1.59 picocuries per gram ( $\mathrm{pCi} / \mathrm{g}$ ), respectively (fig. 11A). As observed elsewhere (Van Metre and others, 1996b), ${ }^{235} \mathrm{U}$ had much lower activities than ${ }^{234} \mathrm{U}$ and ${ }^{238} \mathrm{U}$ in bottom sediments, with concentrations from 0.024 to $0.088 \mathrm{pCi} / \mathrm{g}$ (fig. 11B). Thorium-230 and ${ }^{232}$ Th were also present in all samples from the gravity core at concentrations ranging from 1.40 to 1.79 and 1.12 to $1.57 \mathrm{pCi} / \mathrm{g}$, respectively (fig. 11C). No trend was exhibited for these five naturally occurring radionuclides in the core (fig. 11AC).

Uranium-238, ${ }^{235} \mathrm{U}$, and ${ }^{234} \mathrm{U}$ are naturally occurring isotopes found in rocks and may be important contaminants in uranium mining areas. Substantial uranium mining has not occurred upstream from Cochiti Lake; however, historical uranium releases by LANL into canyons draining into the Rio Grande are a concern. Naturally occurring uranium is dominated by the ${ }^{238} \mathrm{U}$ isotope with minor amounts of ${ }^{235} \mathrm{U}$ and ${ }^{234} \mathrm{U}$. The atom ratio of ${ }^{238} \mathrm{U} /{ }^{235} \mathrm{U}=137.8$ in naturally occurring uranium (Efurd and others, 1993). The ratio of ${ }^{238} \mathrm{U} /{ }^{235} \mathrm{U}$ can differentiate naturally occurring uranium from anthropogenically processed uranium. Natural uranium is processed to enrich ${ }^{235} \mathrm{U}$ relative to ${ }^{238} \mathrm{U}$ for nuclear fuel, significantly lowering the ratio of ${ }^{238} \mathrm{U} /{ }^{235} \mathrm{U}$. The byproduct of processed uranium is depleted in ${ }^{235} \mathrm{U}$ relative to ${ }^{238} \mathrm{U}$, increasing the ratio of ${ }^{238} \mathrm{U} /{ }^{235} \mathrm{U}$. Enriched uranium may have ratios of ${ }^{238} U /{ }^{235} U$ lower than 0.06 , whereas these ratios may be greater than 500 in depleted uranium (Gallaher and others, 1999). The atom ratio of ${ }^{238} \mathrm{U} /$

${ }^{235} \mathrm{U}$ was calculated for each depth interval in the gravity core (fig. 11D). The number of atoms of ${ }^{238} \mathrm{U}$ and ${ }^{235} \mathrm{U}$ was calculated from the activity of the radionuclides using the following equation:

$$
\mathrm{N}=\mathrm{A} / \lambda
$$

where $\mathrm{N}=$ number of atoms;

$\mathrm{A}=$ Activity, in disintegrations per minute (dpm; 1 pCi = $2.22 \mathrm{dpm}$ );

$\lambda=$ decay constant, which is $0.693 / \mathrm{t}_{1 / 2}$; and

$\mathrm{t}_{1 / 2}=$ half-life of the radionuclide.

The atom ratio of ${ }^{238} \mathrm{U} /{ }^{235} \mathrm{U}$ ranges from 99.7 to 331.8 . The analytical total error associated with each sample (table 3) could account for the deviation of the ${ }^{238} \mathrm{U} /$ ${ }^{235} \mathrm{U}$ ratio from that of naturally occurring uranium with the exception of one sample. The sample deposited during the late 1980 's has a ${ }^{238} \mathrm{U} /{ }^{235} \mathrm{U}$ ratio of 331.8. Incorporating the total errors of ${ }^{238} \mathrm{U}$ and ${ }^{235} \mathrm{U}$ lowered this sample's ratio to 152.6 . Depleted uranium could cause the ratio of ${ }^{238} \mathrm{U} /{ }^{235} \mathrm{U}$ to be greater than that of naturally occurring uranium in this sediment interval.

The activity of the $\mathrm{U}$ and $\mathrm{Th}$ radionuclides in the box cores is shown in figure 12. Van Metre and others (1996b) showed $U$ and $T h$ radionuclide activities to correlate positively with the percentage of silt- and clay-sized grains, so radionuclide activities in the box cores did not require normalization with respect to grain size. The activity of the $\mathrm{U}$ and $\mathrm{Th}$ radionuclides is similar to the activity of the samples collected in the gravity core (fig. 12A).

Plutonium is a manmade element that is used in nuclear weapons and generates energy in nuclear reactors. LANL, situated northwest of Cochiti Lake, conducts nuclear technology research and has released plutonium to the environment in the form of airborne emissions and liquid effluents as a result of laboratory operations (Los Alamos National Laboratory, 1995). LANL was established in 1943 and its contribution of radionuclides to the environment has been extensively monitored and studied (Graf, 1994; Los Alamos National Laboratory, 1995). Graf (1994) reported the mean activities of ${ }^{238} \mathrm{Pu}(0.0007 \mathrm{pCi} / \mathrm{g})$ and ${ }^{239,240} \mathrm{Pu}$ $(0.0127 \mathrm{pCi} / \mathrm{g})$ for northern Rio Grande Basin reservoir sediments (Rio Grande, Heron, El Vado, Abiquiu, and Cochiti Reservoirs) for 1982 through 1988. The Rio Grande, Heron, El Vado, and Abiquiu Reservoirs are located upstream from Cochiti Lake. 


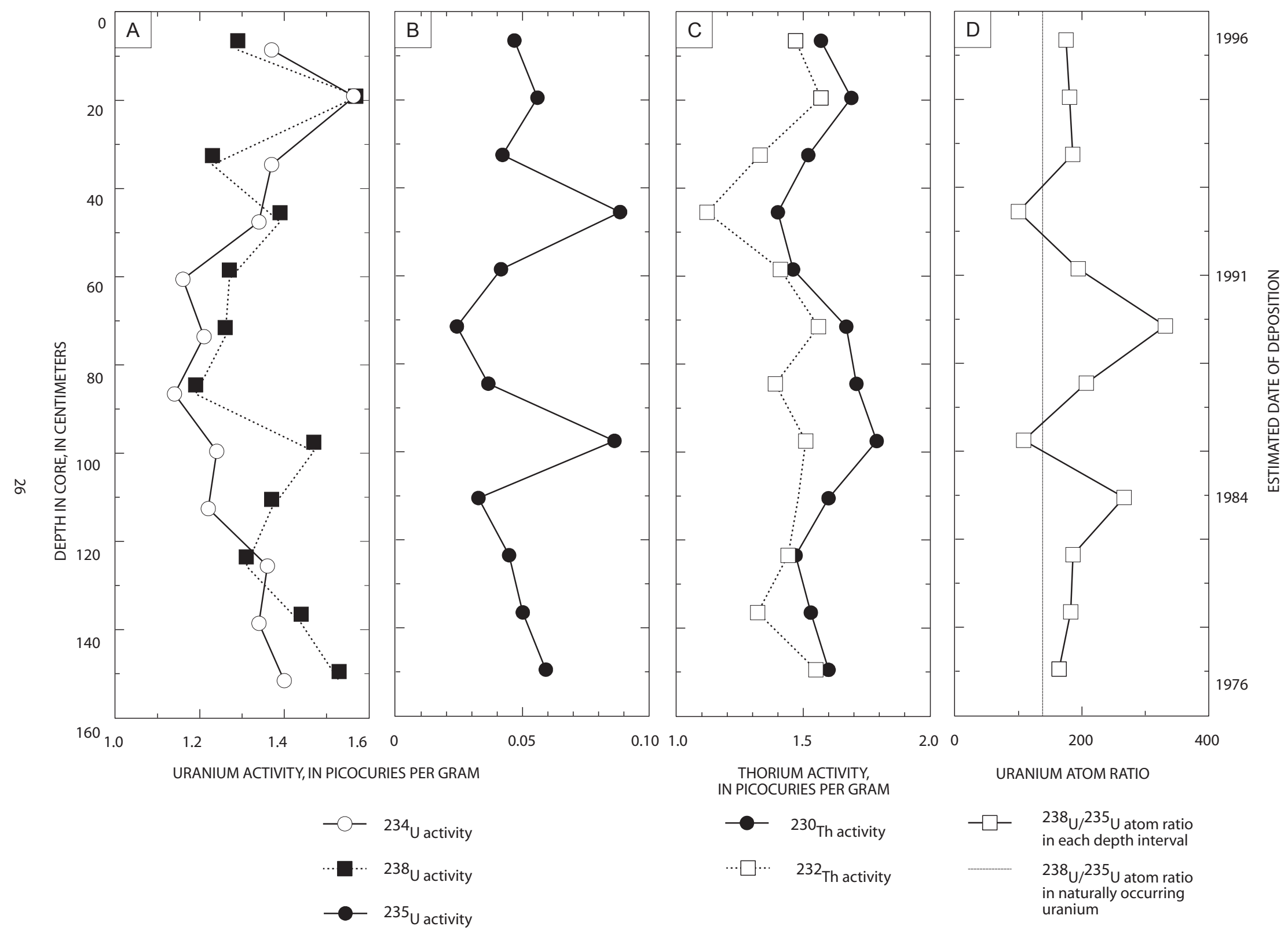

Figure 11. Uranium and thorium radionuclide activities in a gravity core from Cochiti Lake. 


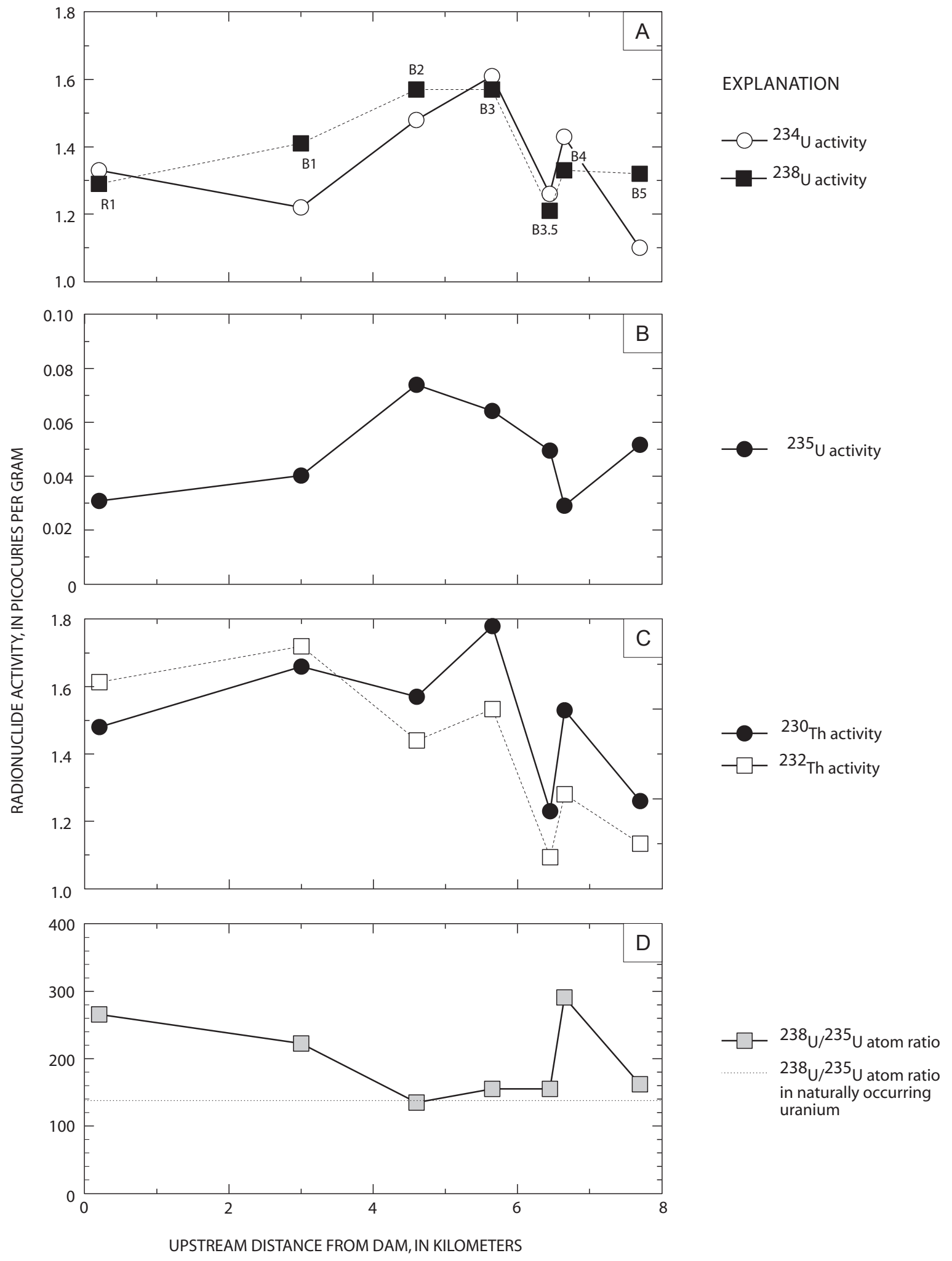

Figure 12. Uranium and thorium radionuclide activities in box cores from Cochiti Lake. 
The activities of ${ }^{238} \mathrm{Pu}$ in the Cochiti Lake gravity core were near the reported mean activity (Graf, 1994) with the exception of a single sample deposited around $1985(97.5 \mathrm{~cm})$, which has an activity (0.004 $\mathrm{pCi} / \mathrm{g}$ ) approximately five times greater than those in the other sediment intervals (fig. 13A). Plutonium-239, 240 activities were more variable, with a peak around 1989 to $1991(58.5$ to $71.5 \mathrm{~cm})$ followed by a step decrease to activities below $0.01 \mathrm{pCi} / \mathrm{g}$ thereafter (fig. 13B). Plutonium-239, 240 activities were at or below the mean activity reported by Graf (1994) except at the 1989 to 1991 peak. LANL has collected surficial sediment samples yearly from Cochiti Lake since 1982. Both ${ }^{238} \mathrm{Pu}$ and ${ }^{239},{ }^{240} \mathrm{Pu}$ activities were greatest in sediments collected in $1989(0.0025$ and 0.0493 pCi/g, respectively) (Graf, 1994; Los Alamos National Laboratory, 1995). Decreasing trends in $\mathrm{Pu}$ in the gravity core appear graphically (fig. 13A, B), but the trends were not statistically significant (Spearman's rank correlation coefficient $=0.54, \mathrm{p}$-value $=0.067$ for ${ }^{238} \mathrm{Pu}$; Spearman's rank correlation coefficient $=0.48$, p-value $=0.11$ for ${ }^{239,}{ }^{240} \mathrm{Pu}$ ).

Soils and river sediments collected between 1978 and 1986 from areas in northern New Mexico and southern Colorado had mean activities of $0.006 \mathrm{pCi} / \mathrm{g}$ for ${ }^{238} \mathrm{Pu}$ and $0.023 \mathrm{pCi} / \mathrm{g}$ for ${ }^{239,}{ }^{240} \mathrm{Pu}$ that were attributed to natural rock-forming minerals and worldwide fallout from atmospheric nuclear weapons tests (Purtymun and others, 1987). The ${ }^{238} \mathrm{Pu}$ activities in all gravity core intervals were less than the worldwide fallout or natural activity (fig. 13A). In all but one interval (middepth of $71.5 \mathrm{~cm}$ ), ${ }^{239,}{ }^{240} \mathrm{Pu}$ activities were less than the worldwide fallout or natural activity (fig. 13B).

Plutonium activities in box core sediment samples are shown in figures $13 \mathrm{C}$ and $\mathrm{D}$. The largest plutonium activities were at coring location B2. Plutonium-238 activities in the box cores were similar to, or greater than, the mean activity reported for northern Rio Grande Basin reservoir sediments by Graf (1994). Only the box core collected at site B2 exceeded the worldwide fallout or natural activity of Purtymun and others (1987). Plutonium-239, 240 activities in all box core sediments were greater than the mean reservoir value of Graf (1994) and were similar to the mean worldwide fallout or natural activity (Purtymun and others, 1987). The ${ }^{238} \mathrm{Pu}$ and ${ }^{239,}{ }^{240} \mathrm{Pu}$ activities in box core sample R1 were more than double the activities at the top of the gravity core. This difference could be indicative of small-scale variations in sediment chemistry (a 13-cm gravity core interval compared to a 5-cm, three-box-core composite sample) or an indication of analytical variability.

The $\mathrm{Pu}$ activities measured for this study are consistent with those measured and reported by Graf (1994) for northern Rio Grande Basin reservoirs, including Cochiti Lake and LANL (1995) for Cochiti Lake. They are similar to, or below, sediment activities reported by Purtymun and others (1987) for northern New Mexico and southern Colorado that were attributed to worldwide fallout or natural activity.

\section{CONCLUSIONS}

Anthropogenic contaminants in Cochiti Lake sediments showed no historical trends with the exception of a modest decreasing trend in total DDT for 1980-92 and were at small concentrations relative to sediment-quality guidelines. The lack of trends implies few new additions of the sediment-bound compounds and elements measured for this study since storage in the reservoir began in 1973. Relatively small concentrations of hydrophobic contaminants including trace elements, organochlorine compounds, PAH's, and naturally occurring radionuclides ( $\mathrm{U}$ and $\mathrm{Th}$ ) are an indication of limited effects by humans. High sedimentation rates, estimated to be about $6.6 \mathrm{~cm} / \mathrm{yr}$ at the coring site near the dam and much greater at upstream sites based on sedimentation surveys, are partly responsible for the relatively "clean" sediments in the reservoir. Large inputs of sediment from undeveloped parts of the watershed dilute any anthropogenic inputs of contaminants from urban, industrial, and agricultural areas. 

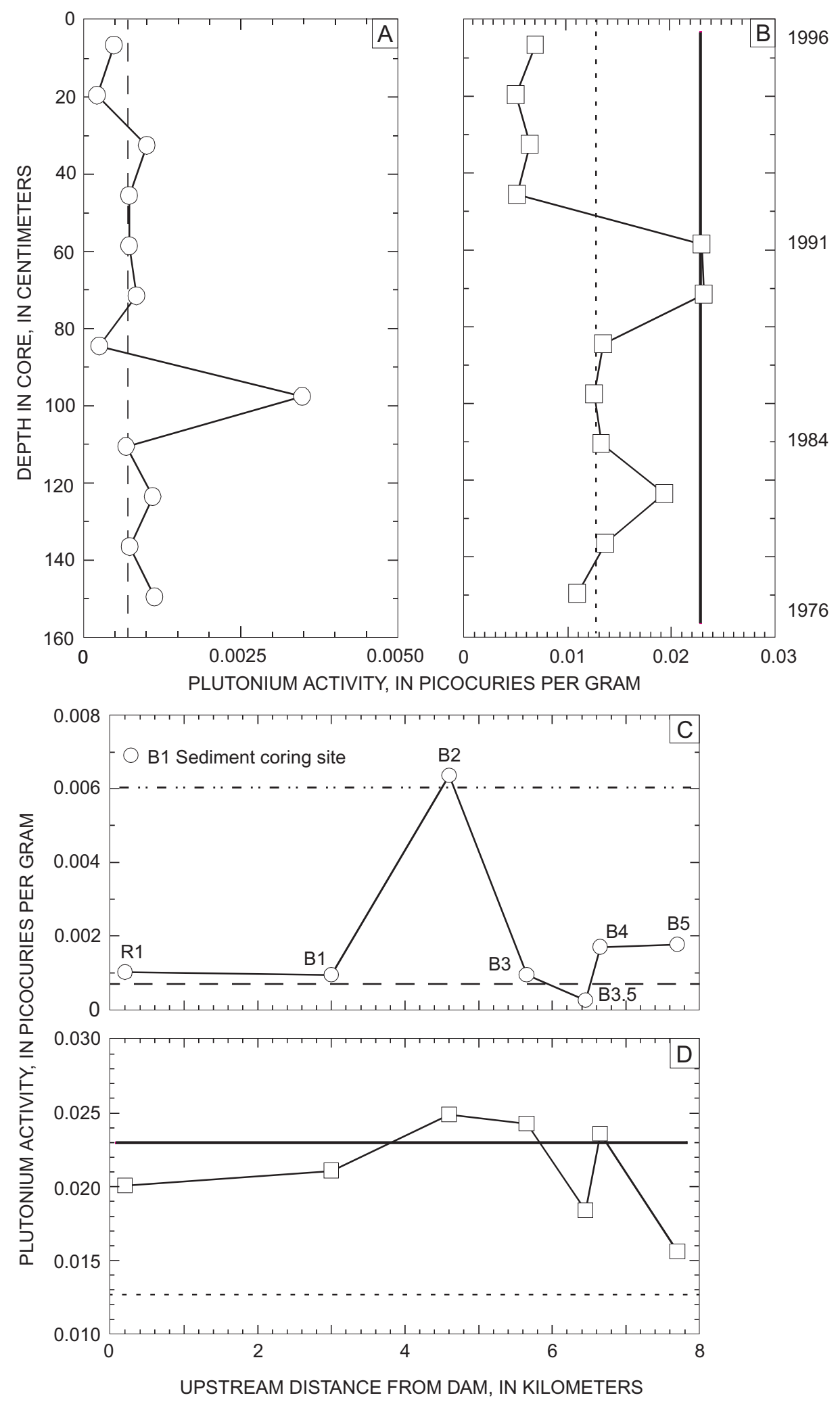

\section{EXPLANATION}

$-\bigcirc-{ }^{238}$ Pu activity

$\square-\square \quad 239,240$ Pu activity

- Mean ${ }^{238} \mathrm{Pu}$ activity in northern Rio Grande Basin reservoir sediments (Graf, 1994)

- .. - $\quad{ }^{238} \mathrm{Pu}$ worldwide fallout and (or) natural activity level (Purtymun and others, 1987)

. . . Mean ${ }^{239,}{ }^{240} \mathrm{Pu}$ activity by northern Rio Grande Basin reservoir sediments (Graf, 1994)

${ }^{239},{ }^{240} \mathrm{Pu}$ worldwide fallout and (or) natural activity level (Purtymun and others, 1987)

Figure 13. Plutonium activities in a gravity core $(A$ and $B)$ and box cores $(C$ and $D)$ from Cochiti Lake. The ${ }^{238} \mathrm{Pu}$ worldwide fallout and (or) natural activity level is greater than the maximum ${ }^{238} \mathrm{Pu}$ activity value shown in (A) and does not appear on the graph. 


\section{REFERENCES CITED}

Alder, A.C., Haggblom, M.M., Oppenheimer, S.R., and Young, Y., 1993, Reductive dechlorination of polychlorinated biphenyls in anaerobic sediments: Environmental Science \& Technology, v. 27, p. 530538.

Borland, J.P., and Ong, K., 1995, Water resources data, New Mexico, water year 1994: U.S. Geological Survey Water-Data Report NM-94-1, 581 p.

Callender, E., and Van Metre, P.C., 1997, Reservoir sediment cores show U.S. lead declines: Environmental Science \& Technology, v. 31, p. 424A-428A.

Canadian Council of Ministers of the Environment, 1998, Canadian sediment-quality guidelines for the protection of aquatic life--Introduction and summary tables, in Canadian environmental quality guidelines, 1998: Canadian Council of Ministers of the Environment, Winnipeg.

Department of the Army, 1996, Cochiti Lake water control manual, Appendix C to Rio Grande Basin, Master water control manual: Department of the Army, Albuquerque District, Corps of Engineers, Albuquerque, N. Mex., $185 \mathrm{p}$.

Efurd, D.W., Rokop, D.J., and Perrin, R.E., 1993, Characterization of the radioactivity in surface waters and sediments collected at the Rocky Flats Facility: Los Alamos National Laboratory Report LA-UR-93-4373, $54 \mathrm{p}$.

Eganhouse, R.P., and Gossett, R.W., 1991, Historical deposition and biogeochemical fate of polycyclic aromatic hydrocarbons in sediments near a major submarine wastewater outfall in Southern California, in Baker, R.A., ed., Organic substances and sediments in water: Boca Raton, Fla., Lewis Publishers, p. 191-220.

Eisenreich, S.J., Capel, P.D., Robbins, J.A., and Boubonniere, R., 1989, Accumulation and diagenesis of chlorinated hydrocarbons in lacustrine sediments: Environmental Science \& Technology, v. 23, p. 11161126.

Fishman, M.J., 1993, Methods of analysis of the U.S. Geological Survey National Water Quality Laboratory-Determination of inorganic and organic constituents in water and fluvial sediments: U.S. Geological Survey Open-File Report 93-125, 217 p.

Foreman, W.T., Connor, B.F., Furlong, E.T., Vaught, D.G., and Merten, L.M., 1994, Methods of analysis by the U.S. Geological Survey National Water Quality Laboratory--Determination of organochlorine insecticides and polychlorinated biphenyls in bottom sediment: U.S. Geological Survey Open-File Report 94-140, 78 p.

Freeman, D.J., and Cattell, C.R., 1990, Woodburning as a source of atmospheric polycyclic aromatic hydrocarbons: Environmental Science \& Technology, v. 24 , p. 1581-1585.
Froelich, P.N., Klinkhammer, G.P., Bender, M.L., Luedtke, N.A., Heath, G.R., Cullen, D., Dauphin, P., Hammond, D., Hartman, B., and Maynard, V., 1979, Early oxidation of organic matter in pelagic sediments of the eastern equatorial Atlantic--Suboxic diagenesis: Geochimica et Cosmochimica Acta, v. 43, p. 10751090.

Furlong, E.T., Vaught, D.G., Merten, L.M., Foreman, W.T., and Gates, P.M., 1996, Methods of analysis by the U.S. Geological Survey National Water Quality Laboratory-Determination of semivolatile organic compounds in bottom sediment by soxlet extraction, gel permeation chromatographic fractionation, and capillary-column chromatography/mass spectrometry: U.S. Geological Survey Open-File Report 95-719, 67 p.

Gallaher, B.M., Efurd, D.W., Rokop, D.J., and Benjamin, T.M., 1999, Plutonium and uranium atom ratios and activity levels in Cochiti Lake bottom sediments provided by Pueblo de Cochiti: Los Alamos National Laboratory Report, LA-13605-MS, 21 p.

Geological Society of America, 1991, The Geological Society of America rock color chart with genuine Munsell color chips: The Geological Society of America, Boulder, Colo., 8 p.

Graf, W.L., 1994, Plutonium and the Rio Grande-Environmental change and contamination in the nuclear age: New York, Oxford University Press, 329 p.

Guy, H., 1969, Laboratory theory and methods for sediment analyses: U.S. Geological Survey Techniques of WaterResources Investigations, book 5, chap. C1, 58 p.

Harvey, R.G., 1991, Polycyclic aromatic hydrocarbons-Chemistry and carcinogenicity: New York, Cambridge University Press, $396 \mathrm{p}$.

Hendricks, T., and Eganhouse, R.P., 1992, Modification and verification of sediment deposition models, final report: Southern California Coastal Water Research Project, Long Beach, Calif., $330 \mathrm{p}$.

Hites, R.A., LaFlamme, R.E., Windsor, J.G., Jr., Farrington, J.W., and Deuser, W.G., 1981, Polycyclic aromatic hydrocarbons in an anoxic sediment core from the Pettaquamscutt River (Rhode Island, U.S.A.): Geochimica et Cosmochimica Acta, v. 44, p. 873-878.

Horowitz, A.J., and Elrick, K.A., 1987, The relation of stream sediment surface area, grain size, and composition to trace element chemistry: Applied Geochemistry v. 2, p. 437-451.

Knox, R.C., Sabatini, D.A., and Canter, L.W., 1993, Subsurface transport and fate processes: Boca Raton, Fla., Lewis Publishers, 430 p. 
LaFlamme, R.E., and Hites, R.A., 1978, The global distribution of polycyclic aromatic hydrocarbons in recent sediments: Geochimica et Cosmochimica Acta, v. 42, p. 289-303.

Lichte, F.E., Golightly, D.W., and Lamothe, P.J., 1987, Inductively coupled plasma-atomic emission spectrometry, in Baedecker, P.A., ed., Methods for geochemical analysis: U.S. Geological Survey Bulletin 1770, p. B1-B10.

Long, E.R., MacDonald, D.D., Smith, S.L., and Calder, F.D., 1995, Incidence of adverse biological effects within ranges of chemical concentrations in marine and estuarine sediments: Environmental Management, v. 19, no. 1, p. 81-97.

Los Alamos National Laboratory, 1995, Environmental surveillance at Los Alamos during 1993: LA-12973ENV.

Lucius, J.E., Olhoeft, G.R., Hill, P.L., and Duke, S.K., 1992, Properties and hazards of 108 selected substances-1992 edition: U.S. Geological Survey Open-File Report 92-527, $554 \mathrm{p}$.

National Academy of Sciences, 1979, Polychlorinated biphenyls: Washington, D.C., National Academy Press, $182 \mathrm{p}$.

Peakall, D.B., 1975, PCB's and their environmental effects: CRC Critical Reviews in Environmental Control, v. 5, no. 5 , p. 469-508.

Prahl, F.G., and Carpenter, R., 1983, Polycyclic aromatic hydrocarbon (PAH)--Phase associations in Washington coastal sediment: Geochimica et Cosmochimica Acta, v. 47, p. 1013-1023.

Pritt, J.W., and Raese, J.W., 1992, Quality assurance/quality control manual--National Water Quality Laboratory: U.S. Geological Survey Open-File Report 92-495, 33 p.

Purtymun, W.D., Peters, R.J., Buhl, T.E., Maes, M.N., and Brown, F.H., 1987, Background concentrations of radionuclides in soils and river sediments in northern New Mexico, 1974-1986: Los Alamos National Laboratory Report LA-11134-MS.

Rapaport, R.A., Urban, N.R., Capel, P.D., Baker, J.E., Looney, B.B., Eisenreich, S.J., and Gorham, E., 1985, "New" DDT inputs to North America--Atmospheric deposition: Chemosphere, v. 14, p. 1167-1173.

Ruddy, B.C., and Hitt, K.J., 1990, Summary of selected characteristics of large reservoirs in the United States and Puerto Rico, 1988: U.S. Geological Survey OpenFile Report 90-163, 295 p.

Smith, J.A., Witkowski, P.J., and Fusillo, T.V., 1988, Manmade organic compounds in the surface water of the United States--A review of current understanding: U.S. Geological Survey Circular 1007, 92 p.

U.S. Environmental Protection Agency, 1983, Analysis of the risks and benefits of seven chemicals used for subterranean termite control: U.S. Environmental
Protection Agency, Office of Pesticides and Toxic Substances, EPA-540/9-83-005.

Van Metre, P.C., Callender, E., and Fuller, C.C., 1997, Historical trends in organochlorine compounds in river basins identified using sediment cores from reservoirs: Environmental Science \& Technology, v. 31, p. 23392344.

Van Metre, P.C., Mahler, B.J., and Callender, E., 1996a, Water-quality trends in the Rio Grande/Rio Bravo Basin using sediment cores from reservoirs: U.S. Geological Survey Fact Sheet FS-221-96, 8 p.

Van Metre, P.C., Wilson, J.T., Callender, E., and Fuller, C.C., 1998, Similar rates of decrease of persistent, hydrophobic and particle-reactive contaminants in riverine systems: Environmental Science \& Technology, v. 32, p. 3312-3317.

Van Metre, P.C., Wirt, L., Lopes, T.J., and Ferguson, S.A., 1996b, Effects of uranium-mining releases on groundwater quality in the Puerco River Basin, Arizona and New Mexico: U.S. Geological Survey Water-Supply Paper 2476, 72 p.

Wershaw, R.L., Fishman, M.J., Grabbe, R.R., and Lowe, L.E., eds., 1987, Methods for the determination of organic substances in water and fluvial sediments: U.S. Geological Survey Techniques of Water-Resources Investigations, book 5, chap. A3, 80 p. 
U.S. Department of the Interior

U.S. Geological Survey, WRD

5338 Montgomery Blvd. NE, Suite 400

Albuquerque, NM 87109-1311

BOOK RATE

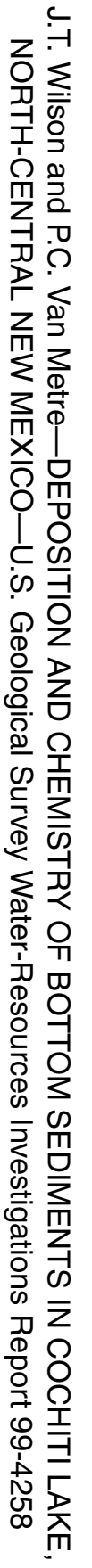

(4) Printed on recycled paper 